\title{
Seasonal and diurnal trends in black carbon properties and co-pollutants in Mexico City
}

\author{
A. Retama ${ }^{1}$, D. Baumgardner ${ }^{2}$, G. B. Raga ${ }^{3}$, G. R. McMeeking ${ }^{2}$, and J. W. Walker ${ }^{2}$ \\ ${ }^{1}$ Dirección de Monitoreo Atmosférico, Secretaría del Medio Ambiente, Mexico City, Mexico \\ ${ }^{2}$ Droplet Measurement Technologies, Boulder, CO, USA \\ ${ }^{3}$ Centro de Ciencias de la Atmósfera, Universidad Nacional Autónoma de México, Ciudad Universitaria, \\ Mexico City, Mexico \\ Correspondence to: D. Baumgardner (darrel.baumgardner@gmail.com)
}

Received: 24 February 2015 - Published in Atmos. Chem. Phys. Discuss.: 29 April 2015

Revised: 5 August 2015 - Accepted: 19 August 2015 - Published: 28 August 2015

\begin{abstract}
The Mexico City metropolitan area (MCMA) is a region that continues to grow in population and vehicular traffic as well as being the largest source of short-lived climate pollutants (SLCP) in Latin America. The local city government has made significant progress in controlling some of these pollutants, i.e., ozone $\left(\mathrm{O}_{3}\right)$ and carbon monoxide (CO), but particulate matter $\left(\mathrm{PM}_{2.5}\right.$ and $\left.\mathrm{PM}_{10}\right)$ and black carbon (BC) have shown a less positive response to mitigation strategies that have been in place for almost 3 decades. For the first time, extended measurements of equivalent black carbon (eBC), derived from light absorption measurements, have been made using a Photoacoustic Extinctiometer (PAX) over a 13 month period from March 2013 through March 2014. The daily trends in workdays (Monday through Saturday) and Sunday eBC, $\mathrm{PM}_{2.5}$ and the co-pollutants $\mathrm{CO}$, $\mathrm{O}_{3}$ and $\mathrm{NO}_{x}$ are evaluated with respect to the three primary seasons in the MCMA: rainy, cold and dry and warm and dry.

The maximum values in all of the particle and gas concentrations were significantly larger (Student's $t$ test, $P<0.05$ ) during the dry periods than in the rainy season. The changes from rainy to dry seasons for eBC, $\mathrm{PM}_{2.5}, \mathrm{CO}, \mathrm{O}_{3}$ and $\mathrm{NO}_{x}$ were 8.8 to $13.1 \mu \mathrm{g} \mathrm{m}^{-3}$ (40\%), 49 to $73 \mu \mathrm{g} \mathrm{m}^{-3}(40 \%), 2.5$ to $3.8 \mathrm{ppm}$ ( $40 \%), 73$ to $100 \mathrm{ppb}(30 \%)$ and 144 to $252 \mathrm{ppb}$ $(53 \%)$, respectively.

The primary factors that lead to these large changes between the wet and dry seasons are the accelerated vertical mixing of boundary layer and free tropospheric air by the formation of clouds that dilutes the concentration of the SLCPs, the decreased actinic flux that reduces the production
\end{abstract}

of ozone by photochemical reactions and the heavy, almost daily rain that removes particulate matter.

A significant "weekend effect" was also identified, particularly the decrease in $\mathrm{BC}$ due to fewer large transport vehicles that are fueled by diesel, which produces a large fraction of the BC. The other co-pollutant concentrations are also significantly less on weekends except for $\mathrm{O}_{3}$ that shows no change in maximum values from workdays to Sundays. This lack of change is a result of the balancing effects of lower precursor gases, i.e., VOCs, offset by lower concentrations of $\mathrm{NO}_{x}$, that is an $\mathrm{O}_{3}$ inhibitor.

A comparison of the average maximum value of eBC measured during the 1 year period of the current study, with maximum values measured in shorter field campaigns in 2000 and 2006, shows no significant change in the eBC emissions over a 14 year period. This suggests that new methods may need to be developed that can decrease potentially toxic levels of this particulate pollutant.

\section{Background}

Short-lived climate pollutants (SLCP) are those gases and particles whose atmospheric lifetimes range from less than a day to a few years (Shindell et al., 2012; Bowerman et al., 2013) and exert a positive radiative forcing to the global climate. These pollutants, black carbon (BC), methane $\left(\mathrm{CH}_{4}\right)$, tropospheric ozone $\left(\mathrm{O}_{3}\right)$ and selected hydrofluorocarbons (HFCs), also impact the environment and have negative effects on human health. Although the SLCPs play a role in the 
radiative balance of the earth and have global impacts, their more immediate effects are observed locally and regionally.

Black carbon has been identified as the atmospheric component whose regional warming effect on climate is second only to carbon dioxide (Bond et al., 2013). Unlike $\mathrm{CO}_{2}$ whose increasing global concentration and long lifetime require an international-scale effort to reduce concentrations, $\mathrm{BC}$ is a contaminant whose negative effects locally can be significantly decreased through local and regional mitigation (Shindell et al., 2012; Bowerman et al., 2013). This is an optimistic possibility since BC is a product of inefficient combustion from motor vehicles (cars, buses and trucks), commercial processes (e.g., brick making, cooking, oil and gas production), residential heating and cooking and open biomass burning (e.g., agricultural clearing and inadvertent forest fires). All of these emission sources lend themselves to a greater level of control through regulatory actions and with technologies that are already available. Likewise, the other co-pollutant SLCPs may be similarly reduced through the measures taken to reduce BC.

The Mexico City metropolitan area (MCMA), referred to as Greater Mexico City, has a population that now exceeds 22 million people, according to the 2014 census, making it the largest urban area in North America. The MCMA is also one of the most polluted megacities in the western hemisphere and a major source of SLCPs that not only affect the local and regional environment but can also contribute to global climate change (Barth and Church,1999; Singh et al., 2009). According to the most recent assessment by the city government (SMA-GDF, 2012) annual emissions of $\mathrm{BC}, \mathrm{PM}_{2.5}, \mathrm{CO}$ and $\mathrm{NO}_{x}$ are 2 kilotons $(\mathrm{Kt}), 9.4,1606$ and $239 \mathrm{Kt}$, respectively.

The Mexico City government established a network of automatic air quality stations in 1986 (Red Automática de Monitoreo Atmosférico - RAMA, http://www.aire.df.gob. $\mathrm{mx} /$ ) to monitor $\mathrm{O}_{3}, \mathrm{CO}, \mathrm{NO}_{x}$ and $\mathrm{SO}_{2}$, adding mass concentration of particles with aerodynamic diameter less than $10 \mu \mathrm{m}\left(\mathrm{PM}_{10}\right)$ in 1991 and less than $2.5 \mu \mathrm{m}\left(\mathrm{PM}_{2.5}\right)$ in 2003. RAMA currently has 29 stations located in the MCMA (Fig. 1, courtesy of the city government's environmental agency, http://www.aire.df.gob.mx/default.php). Until recently, however, there were no measurements of $\mathrm{BC}$ at any of the RAMA stations. The few BC measurements previously available had been taken during short field campaigns. The first published data on BC were by Baumgardner et al. (2000) who analyzed measurements with a particle soot aerosol photometer (PSAP) to derive equivalent black carbon (eBC), the name that has been given to BC derived from measurements of light absorption (Petzold et al., 2013). These measurements were made during a 2 week period in November, 1997 at an elevated site (400 m above the city) in the southwest sector of Mexico City. Additional measurements were made, also with a PSAP, at three RAMA sites in 2000 over a 3 week period in January and February (Baumgardner et al., 2002). In the spring of 2003 and again in 2005, mea- surements were made with a co-located PSAP and a single particle soot photometer (Baumgardner et al., 2007). These were very short measurement campaigns of 1 week each. In 2003, as part of the MCMA-2003 campaign (Molina et al., 2007), a mobile laboratory was deployed at various locations around the city. Filter samples were evaluated with electron microscopy and aerosol mass spectrometry (Johnson et al., 2005) and eBC was derived from an aethalometer, a filter-based instrument like the PSAP (Jiang et al., 2005). Marley et al. (2007) also made measurements of eBC during MCMA-2003 with an aethalometer and compared them with measurements that they had made in 1997.

During the MILAGRO campaign in March 2006 (Molina et al., 2010), measurements of eBC and elemental carbon (EC) were made at various locations within the city (Marley, 2009a, b) and in the regions around the urban area (Baumgardner et al., 2009; Subramanian, 2010).

In 2011, a new instrument, the Photoacoustic Extinctiometer (PAX) was installed at the RAMA supersite located in the north central section of the city (Fig. 1). From 2011 to 2013 the instrument was being evaluated as a possible addition to the RAMA air quality network. In March 2013, the PAX was certified by RAMA as an operational instrument for measuring the optical properties of $\mathrm{BC}$ relevant for climate, i.e., the light-scattering and absorption coefficients, $B_{\text {scat }}$ and $B_{\mathrm{abs}}$ and the derived eBC. We report in this paper the results from a year of continuous observations made by this instrument since March 2013.

Numerous studies have focused on a better understanding of the meteorological processes that transport pollutants from Mexico City and the chemical processes that lead to the production of ozone and aerosol particle mass (e.g., Stephens et al., 2008; Molina et al., 2010 and references therein). There have been no studies, however, that look at how the chemical processes are linked to the seasonal meteorology. The objective of this study is to evaluate the temporal trends in some of the SLCPs $\left(\mathrm{BC}\right.$ and $\left.\mathrm{O}_{3}\right)$ and related co-pollutants $(\mathrm{CO}$, $\mathrm{NO}_{x}$ and $\mathrm{PM}_{2.5}$ ) and show how they are modulated by seasonal variations in temperature, humidity, precipitation and radiation.

This study is an extension of the evaluation of Mexico City pollutants by Stephens et al. (2008) who analyzed daily trends but did not have information on BC. In the following analysis, the diurnal trends in the concentrations of SLCPs over a 13 month period are compared with respect to seasonal climate changes and linked to the underlying physical processes that lead to seasonal differences.

\section{Measurement methodology}

The RAMA "supersite" (Fig. 1) is located in an area of the city that is a mixture of private residences and industry $\left(19^{\circ} 29.0^{\prime} \mathrm{N}, 99^{\circ} 9.85^{\prime} \mathrm{W} ; 2243 \mathrm{~m}\right.$ a.s.1.). The site is approximately $300 \mathrm{~m}$ from a major highway that is a conduit for 


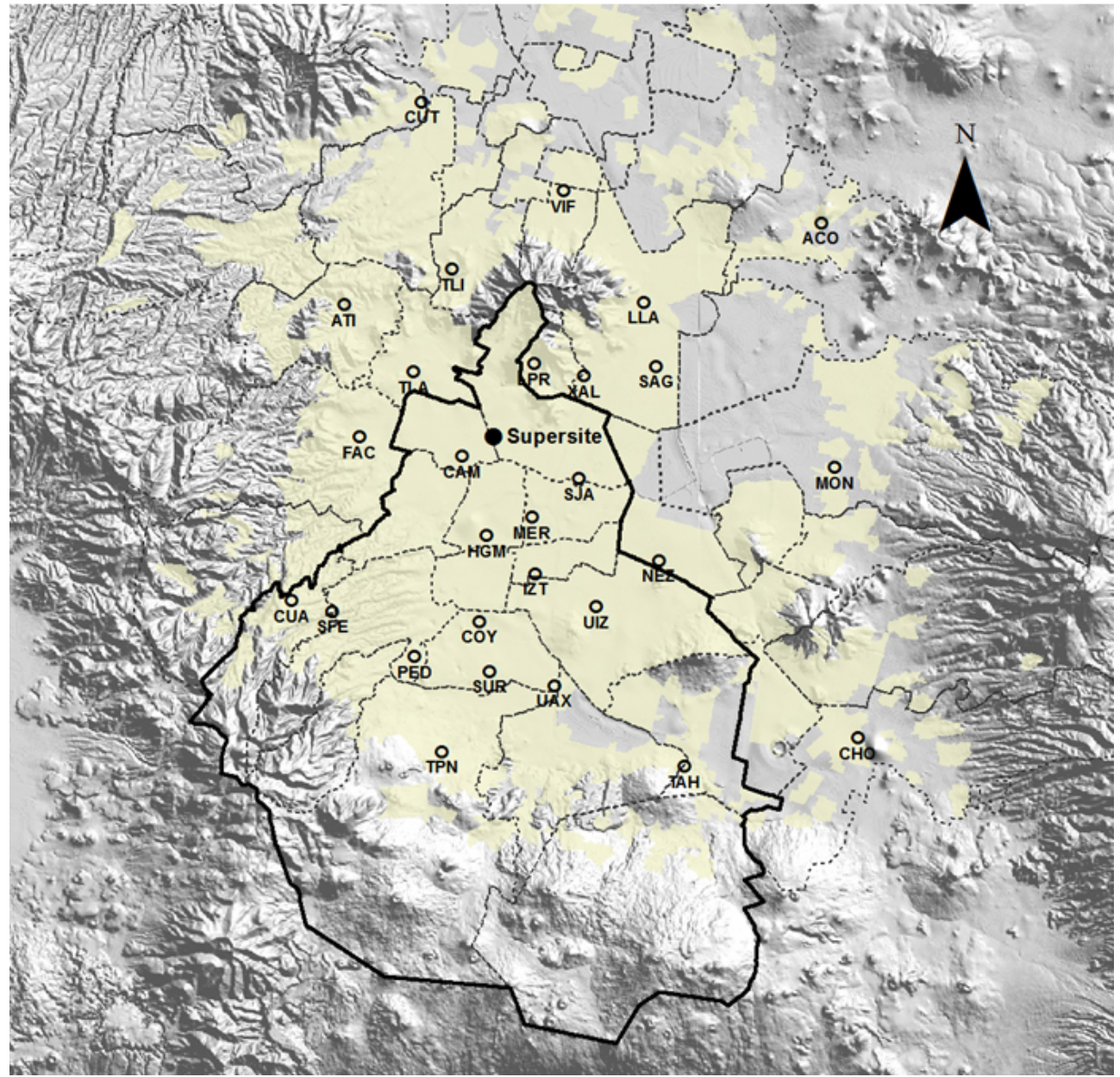

Figure 1. This map of the metropolitan area of Mexico City shows the locations of the RAMA air quality monitoring stations and the location of the supersite where the measurements were made for this paper. Map courtesy of the Mexico City government (http://www.aire.df.gob. $\mathrm{mx} /$ default.php).

north-south traffic. Automobiles, local and regional buses and heavy trucks are responsible for most of the primary pollutants $\left(\mathrm{CO}, \mathrm{NO}_{x}, \mathrm{BC}\right.$ and primary $\left.\mathrm{PM}_{2.5}\right)$. The cars and buses run primarily on unleaded gasoline, whereas the trucks mostly consume diesel that is the major producer of $\mathrm{BC}$. Hence, although the majority of the $\mathrm{BC}$ comes from the trucks, by the time the air reaches the measurement site, the $\mathrm{BC}$ is well-mixed with the $\mathrm{CO}, \mathrm{NO}_{x}$ and other particles that are produced by the cars and buses as well as by the trucks.

\subsection{Meteorology, radiation, gas and $\mathbf{P M}_{2.5}$ measurements}

Temperature and relative humidity are measured using a Met One (Met One Instrument, Grants Pass, OR) model 083E sensor located inside an aspirated radiation shield. Wind speed and direction are measured with a Met One model 010C lightweight three-cup anemometer, and a Met One model 020C lightweight airfoil vane. The temperature and relative humidity sensors are positioned in a meteorological tower $4 \mathrm{~m}$ above the ground. The anemometer and vane are located at the top of the $10 \mathrm{~m}$ meteorological tower. All sensors are calibrated annually. The ultraviolet radiation, over the wavelength range from 320 to $400 \mathrm{~nm}$ (UV-A), is measured with a Solar Light UVA model 501 radiometer that outputs its data in $\mathrm{mW} \mathrm{cm}^{-2}$. The UV-A measurements used in this paper are not made at the "supersite", but are an average from six stations across the city (see Fig. 1): Merced (MER), Montecillo (MON), Pedregal (PED), San Agustin, (SAG), Santa Fe (SFE) and Tlalnepantla (TLA).

Ozone is measured by ultraviolet photometry (Teledyne API model 400E, San Diego CA). The $\mathrm{NO}_{x}$, defined operationally, is measured by chemiluminescence following conversion in a heated molybdenum $\mathrm{NO}_{2}$-to- $\mathrm{NO}$ converter (Teledyne-API model 200E, San Diego, CA). The CO is measured by a gas filter correlation, non-dispersive infrared analyzer (Teledyne API model 300E, San Diego, CA). The 
gas analyzers are tested every 2 weeks with a known standard and calibrated quarterly.

$\mathrm{PM}_{2.5}$ is measured with a TEOM $1400 \mathrm{~A}$ ambient particulate monitor 8500C FDMS (Thermo Scientific, Franklin, MA), with a BGI VSCC $\mathrm{PM}_{2.5}$ cyclone inlet for size selection. $\mathrm{PM}_{2.5}$ hourly concentrations are reported at local temperature and pressure conditions. The TEOM is operated at a temperature of $35^{\circ} \mathrm{C}$ in order to measure dry particle mass.

\subsection{The Photoacoustic Extinctiometer}

The eBC, $B_{\text {scat }}$ and $B_{\text {abs }}$ are derived from the PAX, a sensor that evolved from the Photoacoustic Soot Spectrometer (PASS) developed at the University of Nevada (e.g., Arnott et al., 2005, 2006; Moosmüller et al., 2009) and commercialized by Droplet Measurement Technologies (Chan et al., 2011; Holder et al., 2014; Liu et al., 2014; Nakayama et al., 2015). The PAX performs simultaneous measurements of aerosol scattering and absorption coefficients using a single diode laser modulated at approximately $1500 \mathrm{~Hz}$. The 375 , 405,532 and $870 \mathrm{~nm}$ single wavelength versions of the instrument have identical measurement cells and differ only in a few optical components. The PAX whose measurements are reported in the current study uses the $870 \mathrm{~nm}$ laser.

Figure 2 shows a diagram of the PAX measurement cells. The nominal 1 LPM sample flow first passes a solenoid pinch valve (not shown) that allows for periodic filter sampling to determine the instrument background signals. The lengths of sample tubing between the filter line and sample line are the same to provide the same acoustic properties along both channels. The sample flow passes into an acoustically insulated enclosure containing the sample cells, where it is then split, making opposing 90 degree turns into the scattering and absorption measurement regions. The sample is exhausted through two ports at the ends of the absorption cells before being filtered and pumped out of the instrument. The flows are controlled using critical orifices and do not affect the calculated absorption and scattering coefficients, which depend only on the properties of the sampled particles and geometry of the measurement region. Sample flow does affect the residence time of particles in the measurement cells, which is approximately $7 \mathrm{~s}$.

The absorption cell includes a $0.635 \mathrm{~cm}$ diameter tube $10.8 \mathrm{~cm}$ long, called the resonator. A small microphone located at the top of the resonator detects the pressure perturbations induced by the heating of the light-absorbing particles. The microphone signal is passed through a fast Fourier transform circuit that gives the peak power at the resonator frequency, which is calculated based on the resonator geometry, air pressure, temperature and dew point temperature measured in the cell. The microphone raw pressure signal ( $p_{\text {mic }}$ ) is converted to the raw light absorption coefficient using the equation

$b_{\text {abs,raw }}=\frac{p_{\text {mic }} A \pi^{2} f}{P_{\mathrm{L}}(\gamma-1) Q} \cos \phi_{\text {raw }}$,

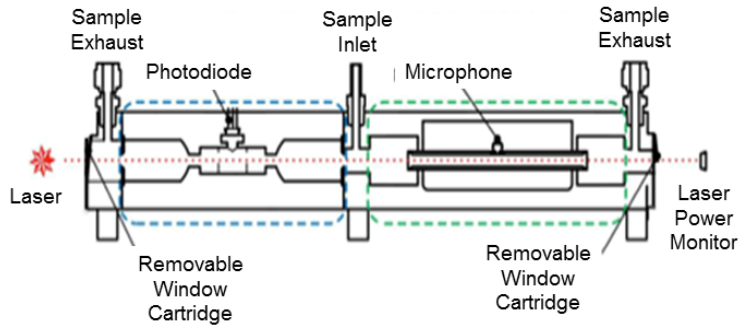

Figure 2. Diagram showing the scattering (blue dashed region) and absorption (green dashed region) cells in the Photoacoustic Extinctiometer (PAX)

where $A$ is the resonator cross section, $f$ is the calculated resonator frequency, $P_{\mathrm{L}}$ is the laser power, $\gamma$ is the ratio of isobaric and isochoric specific heat for air, $Q$ is the calculated resonator quality factor (also calculated from measured cell pressure, temperature and dew point temperature) and $\phi_{\text {raw }}$ is the phase raw absorption signal relative to the phase of the laser power signal plus the phase correction. The phase correction accounts for the difference between the speed of light and sound that translates to a phase shift in the acoustic pressure measured by the microphone relative to the modulated laser power incident on the absorbing material. See Arnott et al. (2005) for more details on applying phase corrections to photoacoustic measurements of light absorption coefficients.

The raw absorption and scattering signals must be corrected for background absorption and scattering signal in the cell to give the desired light absorption and scattering coefficients due to the sampled aerosol particles. Background absorption arises from absorbing gases (not important for the $870 \mathrm{~nm}$ version of the PAX but relevant for shorter wavelength versions), absorption by the cell and particles deposited to the cell surfaces (especially the cell windows) and acoustic and electrical noise that contributes to signal at the resonator frequency. The background scattering is not sensitive to acoustical noise, but is affected by electrical noise and light scattering from the cell surfaces and particles deposited to the cell surfaces and windows. The background signals are measured simultaneously at a user-specified interval, typically once every $10 \mathrm{~min}$, by passing the sample air through a filter before it enters the measurement cell. The background measurement period occurs after a 20 s flush with particlefree air to mix sampled particles out of the measurement cells and lasts $30 \mathrm{~s}$, followed by another $20 \mathrm{~s}$ flush before regular measurements resume. Background absorption and scattering values are saved in the data record and automatically subtracted from the measured raw signals to give the absorption and scattering coefficients in real time. Typically the background drift is small $\left(<3 \mathrm{Mm}^{-1}\right)$ compared to the observed scattering and absorption coefficients, especially in more polluted environments like Mexico City. Background drift occurs due to small changes in the sampling environment, such as temperature and relative humidity. Over longer periods 
of time, backgrounds are affected by contamination on the cell windows and minor changes in the optical alignment. Cleaning and re-alignment of the system can be necessary when the magnitude of the background drift becomes comparable to changes in the scattering and absorption values on the timescales of the filtered background measurements. Post-processing of background values to apply a linearly interpolated correction (using background measurements before and after a sample point) provides a better correction for background drift compared to the standard background correction performed in real time by the instrument.

The PAX absorption and scattering sensitivity depends on the sampling conditions and laser power in the cell. The laser power in turn depends on the quality of the alignment and level of contamination on the cell windows. The scattering sensitivity is mainly limited by the small measurement volume and variability in the particle sample stream. The absorption sensitivity is mainly limited by electrical and acoustical noise that cannot be distinguished from the true particle signal. While noise in the sampling environment can reach the acoustic cell through vibrations in the case, a bigger factor is acoustical noise transmitted through the sampling line directly into the resonator. Helmholtz notch filters can be inserted into the sampling line to filter noise at the measurement frequency in environments with high acoustic noise and relatively low aerosol loadings. In Mexico City, however, these were not necessary because the PAX was installed in a temperature- and noise-controlled environment with minimal acoustic noise.

Figure 3 shows the corrected absorption coefficients and Allan variance plot for the absorption signal measured during overnight sampling of filtered air with an $870 \mathrm{~nm}$ PAX. The instrument performed a background measurement approximately every $10 \mathrm{~min}$, which corrected for the instrument drift on timescales longer than $10 \mathrm{~min}$, so the variance is only shown up to a $5 \mathrm{~min}$ averaging interval. At the highest temporal resolution of $1 \mathrm{~s}$, the variance was $0.14 \mathrm{Mm}^{-1}$, equivalent to about $0.03 \mu \mathrm{g} \mathrm{m}^{-3}$ black carbon using the factoryapplied mass-specific absorption cross section (MAC) of $4.74 \mathrm{~m}^{2} \mathrm{~g}^{-1}$. This is the value at $870 \mathrm{~nm}$, derived using the $\lambda^{-1}$ correction to the $7.5 \mathrm{~m}^{2} \mathrm{~g}^{-1}$ recommended by Bond and Bergstrom (2006). The three-sigma sensitivity for $1 \mathrm{~s}$ averaging was $1.1 \mathrm{Mm}^{-1}\left(0.23 \mu \mathrm{g} \mathrm{m}^{-3} \mathrm{BC}\right)$. The values are a "best case" scenario where the environmental conditions were very stable (running overnight in an empty laboratory) and because the particle filter also acted to block acoustical noise from the sampling environment from reaching the cell. We have observed $1 \mathrm{~s}$ variance in PAX absorption signals ranging from $\sim 1-5 \mathrm{Mm}^{-1}$ depending on the sample environment.

The PAX uses a wide-angle $\left(6-174^{\circ}\right)$ integrating reciprocal nephelometer to measure the light-scattering coefficient. The scattering detector consists of a Teflon diffuser placed in front of a photodiode (Fig. 2). The scattering measurement responds to all particle types regardless of chemical makeup, mixing state, or morphology.
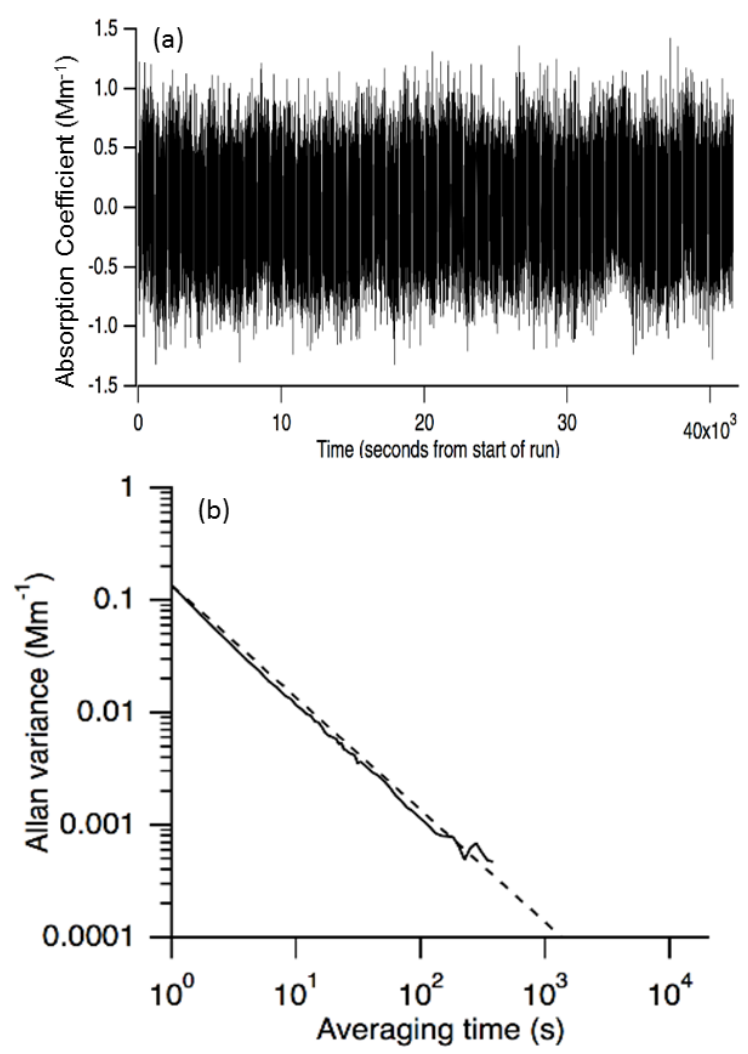

Figure 3. Background-corrected absorption coefficients (a) and Allan variance (b) measured by an $870 \mathrm{~nm}$ PAX sampling filtered laboratory air overnight in a temperature-controlled environment. The dashed line in (b) gives the variance for white noise.

The PAX is calibrated through a two-step process by first introducing high concentrations of purely light-scattering particles followed by high concentrations of partially absorbing particles to the measurement cells (Arnott et al., 2000; Nakayama et al., 2015). The concentrations must be high enough to allow direct measurement of the extinction coefficient $\left(b_{\text {ext }}\right)$ from the reduction in laser power measured at the laser power monitor (Fig. 2) using Beer's law:

$b_{\mathrm{ext}}=-\frac{1}{l} \ln \frac{I}{I_{0}} 10^{6}\left[\mathrm{Mm}^{-1}\right]$,

where $I$ is the average laser power measured when the high concentration of particles is being sampled, $I_{0}$ is the average laser power immediately before and after the high concentrations are introduced to the cell and $l$ is the path length of the laser beam through the entire optical cavity (scattering region and absorption region) between the two windows, which for the PAX is $0.354 \mathrm{~m}$.

Ignoring truncation in the nephelometer cell, an error that is of order 6\% (Nakayama et al., 2015), the measured extinction coefficient equals the measured scattering coefficient for purely scattering particles (e.g, nebulized, dry ammonium sulfate). The relationship between the measured extinction 
and scattering coefficients are fit using a linear regression giving a calibration factor for the scattering measurement. Introducing calibration particles that have non-zero absorption means the measured extinction equals the now-calibrated scattering coefficient plus the absorption coefficient. Subtracting the measured scattering coefficient from the extinction coefficient determined from Beer's law gives the absorption coefficient, which can be regressed against the measured absorption coefficient to obtain a second calibration factor for the absorption cell. One major uncertainty introduced by this method of calibration is it assumes the measured particles have similar scattering-phase functions so the truncation error in the scattering cell cancels.

The PAX measures the light-scattering and absorption coefficients, $B_{\text {scat }}$ and $B_{\text {abs }}$, directly using the in-line nephelometer and photoacoustic technique, respectively. The single scattering albedo (SSA), defined as the ratio of $B_{\text {scat }}$ to the sum of $B_{\text {scat }}$ and $B_{\text {abs }}$ (extinction coefficient) is also derived and recorded, along with the eBC that is derived from the $B_{\text {abs }}$ as described previously.

The PAX was operated with a $\mathrm{PM}_{2.5}$ cyclone particle separator on the inlet in order to remove larger particles and the particle stream was also dried using a diffusion drier in order to minimize measurement effects at high relative humidity (e.g., Lewis et al., 2009; Murphy, 2009) and also to provide the scattering coefficients of dry particles only. The PAX was connected to the cyclone by $3 / 8$ " conductive tubing. Transmission losses are insignificant at the flow rate of $1 \mathrm{Lpm}$, based on calculations made using the Aerocalc program developed by Baron and Willeke (2001).

The uncertainty in the measured $B_{\text {scat }}$ is ca. $\pm 10 \%$ due to the accuracy with which the instrument can be calibrated, the truncation error and aerodynamic losses in the inlet system that brings the ambient air into the sample cavity. The uncertainty in the measured $B_{\text {abs }}$ is ca. $\pm 20 \%$. This uncertainty stems primarily from the accuracy of the calibration but the losses in the inlet system also contribute to the overall accuracy. Given the range of possible MAC values that depend on the composition and size distribution of the black carbon (Bond and Bergstrom, 2006), the uncertainty in the MAC is of order $50 \%$ and hence the derived eBC from $B_{\text {abs }}$ is approximately $55-60 \%$. In addition, Bond et al. (2006) show that BC coated by non-light-absorbing material can cause a lensing effect that leads to enhanced absorption, perhaps as much as a factor of 1.5; hence, the derived $\mathrm{eBC}$ mass concentrations may be as much as $50 \%$ higher than the actual concentration of $\mathrm{BC}$ due to this coating effect.

\section{Measurements and analysis}

The meteorology, gas and particle measurements were made at the RAMA supersite from 6 March 2013 to 31 March 2014. Mexico City is located in a sub-tropical zone where the seasons can be generally separated into three periods: (1) the rainy season extends from approximately June until October with an average annual rainfall of more than $1000 \mathrm{~mm}$, (2) the cool, dry season, from November to March and (3) the warm, dry period from April through May. The starting and ending dates for these seasons will vary from year to year but these three seasonal periods will be used in the analysis as an operational definition, abbreviated from hereon as "rainy season" (RS), cold and dry season (CDS) and warm and dry season (WDS). During the dry months, clear sky conditions lead to a strong thermal inversion at night (Collins and Scott, 1993). This persists until several hours after sunrise when it is eroded by turbulent mixing, generated by strong solar heating of the surface.

During the RS, the interaction of the predominant easterly winds with the mountains that surround the Mexico City basin force upward motions and convection. Early mornings are typically clear during this season, but thermal inversions are infrequent due to the high moisture content in the atmosphere. Solar heating during the mornings leads to the development of turbulent eddies that vertically mix the pollutants emitted at the surface. Convection develops over the mountains, resulting in further dilution of pollutants due to the vertical updrafts within clouds. The precipitation that develops from the convective clouds has a large gradient within the basin (Jáuregui, 1971), from around $400 \mathrm{~mm} \mathrm{yr}^{-1}$ in the northeast to almost $1200 \mathrm{~mm} \mathrm{yr}^{-1}$ in the southwestern part of the city. Figure 4 shows the daily precipitation during the period of the research study, showing that in 2013 the rain began in the middle of May and ended in the first week of November. It rained almost every day, some days more heavily than others. In this study, the RS extends from 11 May to 7 November 2013. Only days when the rain exceeded $2 \mathrm{~mm}$ are included in the present study.

The concentration of gases and aerosols within the boundary layer is controlled by the balance between the emission rates of primary pollutants (i.e., $\mathrm{CO}, \mathrm{NO}_{x}$, volatile organic compounds, VOC and $\mathrm{eBC}$ ), the rate of secondary production due to photochemical reactions of $\mathrm{O}_{3}$ and $\mathrm{PM}_{2.5}$ and the rate of dilution by mixing with tropospheric air. Not only does this balance vary with the season, but because the emissions patterns change from workdays (Monday through Saturday) to Sundays, we would expect to observe differences in the trends of SLCPs when comparing these two seasons.

\subsection{Seasonal trends}

The average, median, daily average maxima and the quantiles values at 5, 25, 75 and $95 \%$ were calculated for $\mathrm{CO}$, $\mathrm{NO}_{x}$ and $\mathrm{O}_{3}$ and are shown in Fig. 5a-c by season, workdays and Sundays. The box and whisker plots show median (horizontal line within the box), $25 \%$ quantile (bottom of box), $75 \%$ quantile (top of box), $5 \%$ quantile (bottom whisker) and $95 \%$ quantile (top whisker). In addition the average of the daily maxima are shown with the red filled circles. The same information for eBC, $\mathrm{PM}_{2.5}, B_{\text {scat }}$ and SSA is shown 


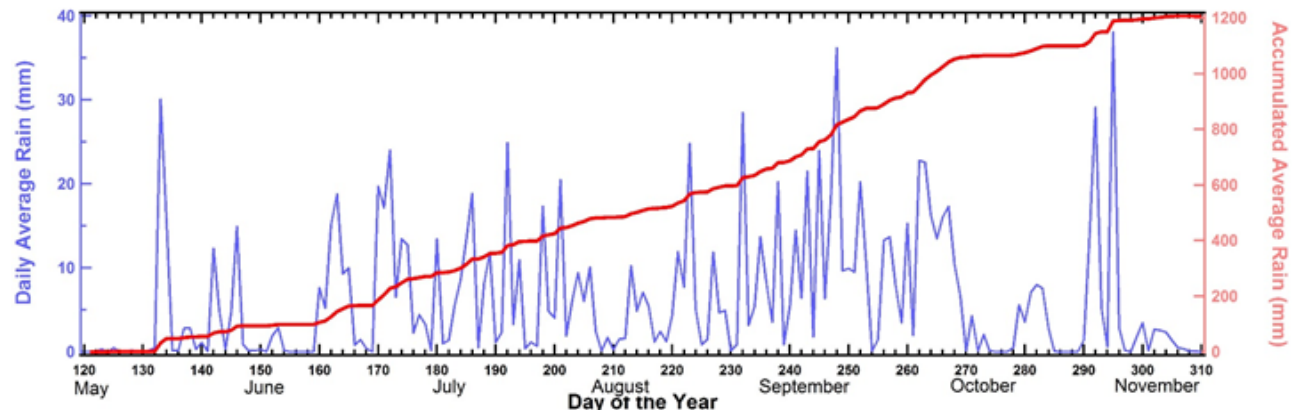

Figure 4. In this time series, the daily accumulated rain is shown, along with the accumulated precipitation beginning on 1 May.
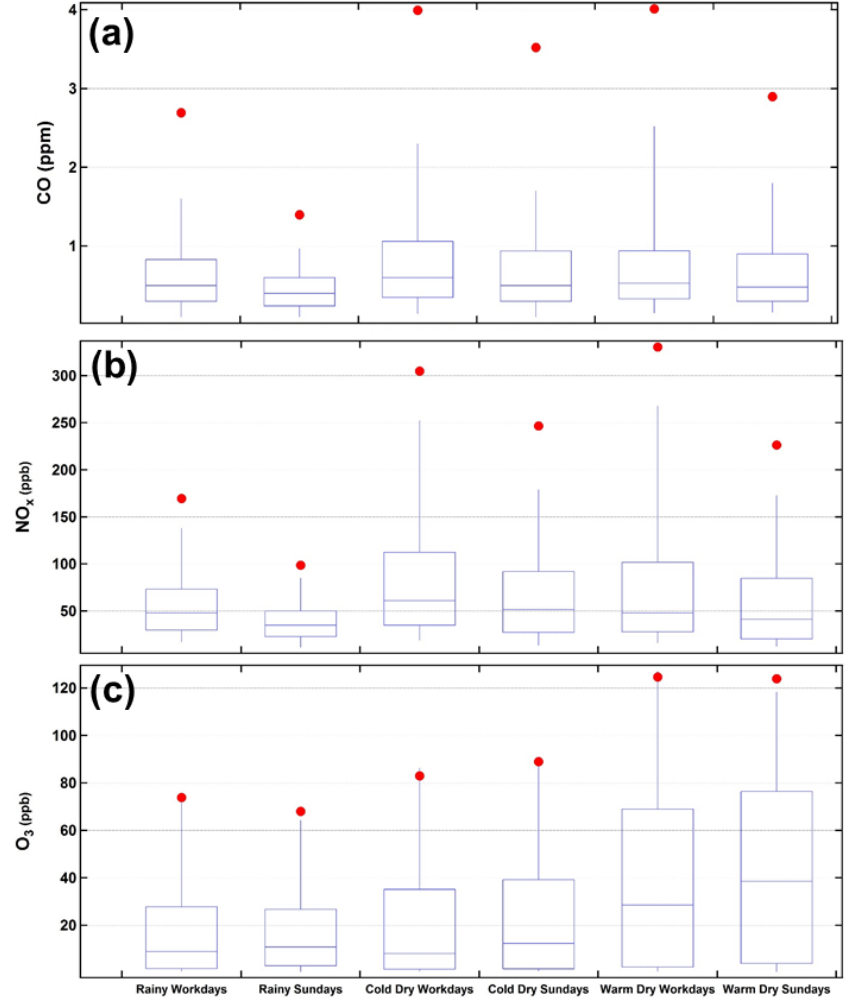

Figure 5. The box and whisker plots show median (horizontal line within the box), $25 \%$ quantile (bottom of box), $75 \%$ quantile (top of box), $5 \%$ quantile (bottom whisker) and $95 \%$ quantile (top whisker). In addition the average of the daily maxima are shown with the red filled circles. The trends in these statistics as a function of season, workdays and Sundays are plotted for (a) $\mathrm{CO}$, (b) $\mathrm{NO}_{x}$ and (c) $\mathrm{O}_{3}$.

in Fig. 6a-d, respectively. The values used to generate these graphs are tabulated in Table 1.

Table 2 summarizes the average and standard deviations about the average maximum daily values tabulated by season, workdays and Sundays. A Student's $t$ test was applied to the differences and the significance was evaluated at a confidence level of $P<0.10$, i.e., that there is less than a $10 \%$
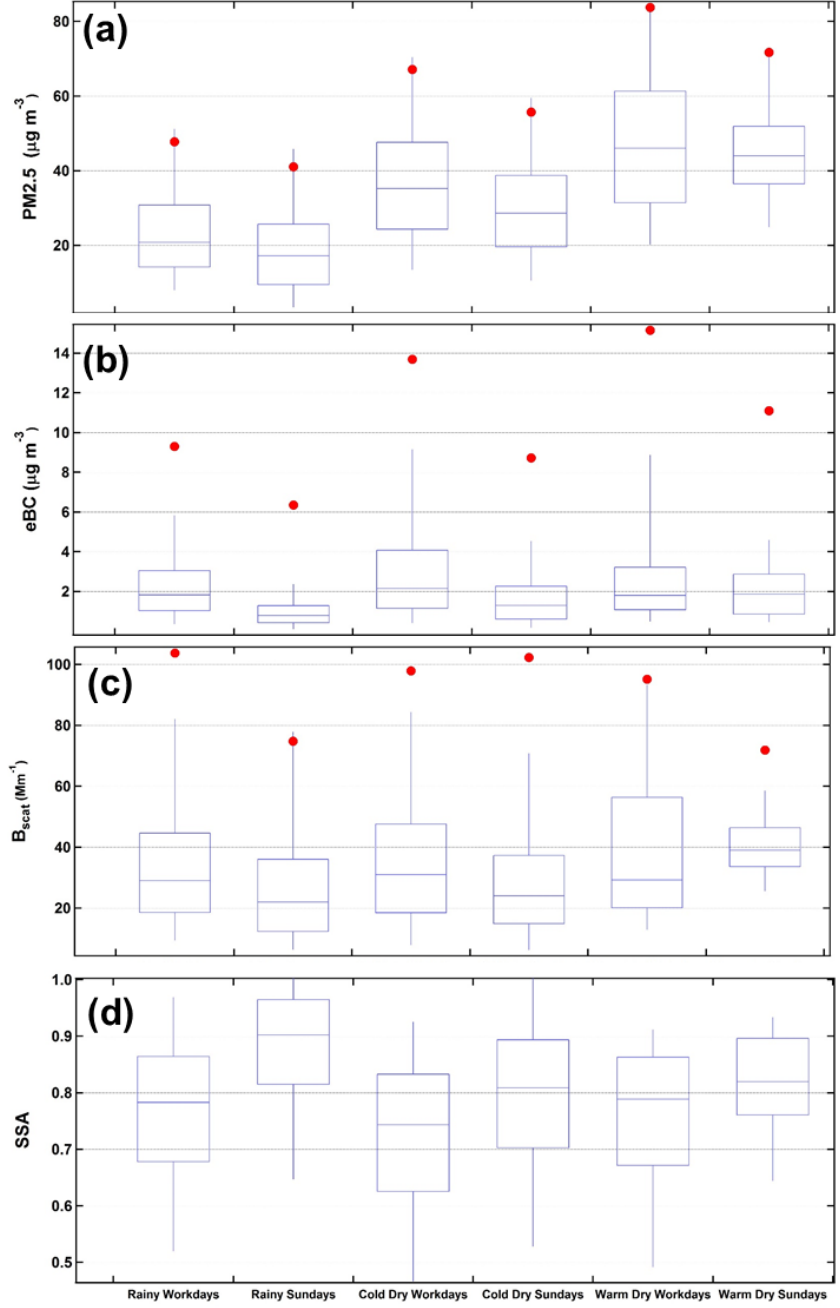

Figure 6. The same as Fig. 5 but for (a) $\mathrm{PM}_{2.5}$, (b) eBC, (c) $B_{\text {scat }}$ and (d) SSA.

probability that the observed differences are due to chance. For each season and each measured parameter, the significance of the differences between the workday and Sunday values was tested using the hypothesis that the average values 
Table 1. Daily and seasonal statistics.

\begin{tabular}{|c|c|c|c|c|c|c|c|}
\hline Parameter & Statistic & $\begin{array}{r}\text { Rainy } \\
\text { workdays }\end{array}$ & $\begin{array}{r}\text { Rainy } \\
\text { Sundays }\end{array}$ & $\begin{array}{l}\text { Cold-dry } \\
\text { workdays }\end{array}$ & $\begin{array}{l}\text { Cold-dry } \\
\text { Sundays }\end{array}$ & $\begin{array}{l}\text { Warm-dry } \\
\text { workdays }\end{array}$ & $\begin{array}{r}\text { Warm-dry } \\
\text { Sundays }\end{array}$ \\
\hline \multirow[t]{5}{*}{$\mathrm{CO}$ (ppm) } & Average & 0.64 & 0.43 & 0.83 & 0.69 & 0.81 & 0.68 \\
\hline & Median & 0.50 & 0.4 & 0.60 & 0.50 & 0.53 & 0.48 \\
\hline & Q75 & 0.83 & 0.6 & 1.06 & 0.94 & 0.94 & 0.9 \\
\hline & Q95 & 1.6 & 0.97 & 2.30 & 1.70 & 2.52 & 1.8 \\
\hline & Maximum & 2.69 & 0.43 & 3.99 & 3.52 & 4.01 & 2.90 \\
\hline \multirow[t]{5}{*}{$\mathrm{O}_{3}(\mathrm{ppb})$} & Average & 19 & 19 & 22 & 25 & 41 & 45 \\
\hline & Median & 9 & 11 & 8 & 12 & 29 & 39 \\
\hline & Q75 & 28 & 27 & 35 & 39 & 69 & 76 \\
\hline & Q95 & 73 & 64 & 86 & 87 & 127 & 118 \\
\hline & Maximum & 74 & 68 & 83 & 89 & 125 & 124 \\
\hline \multirow[t]{5}{*}{$\mathrm{NO}_{x}(\mathrm{ppb})$} & Average & 58 & 40 & 82 & 67 & 80 & 61 \\
\hline & Median & 48 & 35 & 88 & 69 & 48 & 41 \\
\hline & Q75 & 73 & 50 & 61 & 52 & 102 & 85 \\
\hline & Q95 & 138 & 85 & 112 & 92 & 268 & 173 \\
\hline & Maximum & 170 & 99 & 252 & 179 & 330 & 226 \\
\hline \multirow[t]{5}{*}{$\mathrm{PM}_{2.5} \mu \mathrm{g} \mathrm{m}^{-3}$} & Average & 25 & 20 & 38 & 31 & 48 & 45 \\
\hline & Median & 21 & 17 & 35 & 29 & 46 & 44 \\
\hline & Q75 & 31 & 26 & 48 & 39 & 61 & 52 \\
\hline & Q95 & 51 & 46 & 70 & 60 & 83 & 71 \\
\hline & Maximum & 48 & 41 & 67 & 56 & 84 & 72 \\
\hline \multirow[t]{5}{*}{$\mathrm{eBC} \mu \mathrm{g} \mathrm{m}^{-3}$} & Average & 2.3 & 0.9 & 3.1 & 1.7 & 2.8 & 2.1 \\
\hline & Median & 1.8 & 0.8 & 2.2 & 1.3 & 1.8 & 1.9 \\
\hline & Q75 & 3.0 & 1.3 & 4.1 & 2.7 & 3.2 & 2.9 \\
\hline & Q95 & 5.8 & 2.4 & 9.2 & 4.5 & 8.9 & 4.6 \\
\hline & Maximum & 9.3 & 6.4 & 13.7 & 8.7 & 15.1 & 11.1 \\
\hline \multirow[t]{4}{*}{ SSA } & Average & 0.76 & 0.84 & 0.72 & 0.78 & 0.75 & 0.81 \\
\hline & Median & 0.78 & 0.90 & 0.74 & 0.81 & 0.79 & 0.82 \\
\hline & Q75 & 0.86 & 0.96 & 0.83 & 0.89 & 0.86 & 0.90 \\
\hline & Q95 & 0.97 & 1.0 & 0.93 & 1.00 & 0.91 & 0.93 \\
\hline \multirow[t]{5}{*}{$B_{\text {scat }}$} & Average & 35 & 28 & 37 & 32 & 41 & 40 \\
\hline & Median & 29 & 22 & 31 & 24 & 29 & 39 \\
\hline & Q75 & 45 & 36 & 48 & 37 & 56 & 46 \\
\hline & Q95 & 82 & 78 & 84 & 71 & 93 & 59 \\
\hline & Maximum & 104 & 75 & 98 & 102 & 95 & 72 \\
\hline
\end{tabular}

were from the same population. This hypothesis was rejected when the value of $T>|1.7|$, the critical value for $P<0.10$ with the pooled degrees of freedom of the two samples in each comparison. In the Table, underlined numbers $i$ had Sunday values significantly smaller than for the workdays, i.e., the null hypothesis that they were from the same population was rejected. Likewise, the numbers in bold were the cases when the Sunday values exceeded the workday values.

Using the same approach the difference in the average maximum values between each of the three seasons was tested (last three columns in Table 1). The underlined numbers indicate a significant decrease in a parameter value from one season to the next and the numbers in bold highlight sig- nificant increases. The value in parentheses in each of these cells is the computed value of the $t$ statistic.

Median concentrations of $\mathrm{CO}$ and $\mathrm{NO}_{x}$ (Fig. $5 \mathrm{a}$ and b, respectively) do not significantly change with season, whereas there is a clear increase in $\mathrm{O}_{3}$ (Fig. 5c) during the WDS compared to either the RS or CDS. The maximum concentrations for all three of the gas species increase significantly (Table 2) in the dry seasons (cold and warm) compared to the RS. This increase is seen for workdays as well as Sundays. A significant increase from the CDS to the WDS is only observed in the $\mathrm{O}_{3}$ concentrations, due to the larger actinic flux late in the spring. Of note is that the maximum $\mathrm{CO}$ concentrations on Sundays actually decrease between the CDS and WDS (numbers in underlined italics in Table 2). 
Table 2. Daily and seasonal maxima. Underlining indicates significant decrease at $P<0.10$. Bold indicates significant increase.

\begin{tabular}{|c|c|c|c|c|c|c|c|}
\hline Parameter & $\begin{array}{l}\text { Day of } \\
\text { the week }\end{array}$ & $\begin{array}{r}\text { Rainy } \\
\text { maximum } \\
(\mathrm{SD}-\%)\end{array}$ & $\begin{array}{r}\text { Cold-dry } \\
\text { maximum } \\
(\mathrm{SD}-\%)\end{array}$ & $\begin{array}{r}\text { Warm-dry } \\
\text { maximum } \\
(\mathrm{SD}-\%)\end{array}$ & $\begin{array}{r}\text { Rainy to } \\
\text { cold } \\
\% \text { diff }\end{array}$ & $\begin{array}{l}\text { Rainy to } \\
\text { warm } \\
\text { rence }(t \text { tes }\end{array}$ & $\begin{array}{l}\text { Cold to } \\
\text { warm } \\
\text { Values) }\end{array}$ \\
\hline \multirow[t]{2}{*}{$\mathrm{CO}(\mathrm{ppm})$} & Mon-Sat. & $2.6(61)$ & $4.0(64)$ & $4.0(50)$ & $41(3.9)$ & $43(3.3)$ & $0(0.3)$ \\
\hline & Sunday & $1.3(30)$ & $3.5(68)$ & $2.8(32)$ & $92(4.0)$ & $74(3.1)$ & $-21(-1.0)$ \\
\hline \multirow[t]{2}{*}{$\mathrm{O}_{3}(\mathrm{ppb})$} & Mon-Sat. & $73(38)$ & $82(37)$ & $124(25)$ & $12(2.2)$ & $52(8.1)$ & $41(6.9)$ \\
\hline & Sunday & $67(43)$ & $88(31)$ & $123(13)$ & $28(2.1)$ & $59(5.0)$ & $34(3.8)$ \\
\hline \multirow[t]{2}{*}{$\mathrm{NO}_{x}(\mathrm{ppb})$} & Mon-Sat. & $169(42)$ & $304(41)$ & $330(37)$ & $58(10.3)$ & $65(7.2)$ & $9(1.2)$ \\
\hline & Sunday & $98(32)$ & $246(45)$ & $226(26)$ & $87(6.1)$ & $80(4.5)$ & $-8(-0.5)$ \\
\hline \multirow[t]{2}{*}{$\mathrm{PM}_{2.5} \mu \mathrm{g} \mathrm{m}^{-3}$} & Mon-Sat. & $47(36)$ & $67(31)$ & $83(30)$ & $36(7.7)$ & $56(7.8)$ & $22(3.5)$ \\
\hline & Sunday & $\underline{41(39)}$ & $55(34)$ & $\underline{71(21)}$ & $30(2.3)$ & $54(3.7)$ & $26(2.1)$ \\
\hline \multirow[t]{2}{*}{$\mathrm{eBC} \mu \mathrm{g} \mathrm{m}^{-3}$} & Mon-Sat. & $9.3(46)$ & $13.6(47)$ & $15.1(59)$ & $38(6.1)$ & $48(2.5)$ & $-11(-0.7)$ \\
\hline & Sunday & $6.3(114)$ & $8.7(70)$ & $11.1(59)$ & $32(1.1)$ & $66(2.5)$ & $-25(-2.0)$ \\
\hline \multirow[t]{2}{*}{ SSA } & Mon-Sat. & $0.75(14)$ & $0.71(15)$ & $0.75(14)$ & $-5(-2.5)$ & $0(0)$ & $0(0)$ \\
\hline & Sunday & $0.84(11)$ & 0.77 (15) & $0.81(11)$ & $-8(-1.8)$ & $0.3(0.3)$ & $-3(-0.3)$ \\
\hline \multirow[t]{2}{*}{$B_{\text {scat }} \mathrm{Mm}^{-1}$} & Mon-Sat. & $103(43)$ & $98(45)$ & $95(51)$ & $-6(-1.0)$ & $8(0.5)$ & $2(0.1)$ \\
\hline & Sunday & $74(48)$ & $102(68)$ & $71(22)$ & $32(1.7)$ & $4(0.3)$ & $-35(-2.2)$ \\
\hline
\end{tabular}

A "weekend effect" is observed for $\mathrm{CO}, \mathrm{NO}_{x}$ and $\mathrm{O}_{3}$. The maximum $\mathrm{CO}$ and $\mathrm{NO}_{x}$ concentrations decrease between workdays and Sundays by more than $30 \%$ during all three seasons (Table 2). As discussed by Stephens et al. (2008) the lack of a decrease in the $\mathrm{O}_{3}$ concentrations on Sundays is a "weekend effect" because with the decrease in VOCs (CO is a surrogate for VOCs), the $\mathrm{O}_{3}$ was expected to decrease as well. As detailed by Stephens et al. (2008) for Mexico City in particular, there are several possible mechanisms responsible for this behavior; however, the one that was discussed as most plausible is related to the inhibition of $\mathrm{O}_{3}$ by $\mathrm{NO}_{x}$ under VOC-limited conditions. The production of $\mathrm{O}_{3}$ is positively correlated with VOC emissions and negatively correlated with $\mathrm{NO}_{x}$. Since the $\mathrm{CO}$ (VOC) and $\mathrm{NO}_{x}$ are both decreasing, there is a balancing effect on $\mathrm{O}_{3}$ production, i.e., less production from VOC reactions but less inhibition from $\mathrm{NO}_{x}$

Figure $6 \mathrm{a}$ and $\mathrm{b}$ display the same grouping of comparisons as Fig. 5 but for the mass concentrations of $\mathrm{PM}_{2.5}$ and eBC. The median $\mathrm{PM}_{2.5}$ concentrations increase between RS and CDS and between CDS and WDS. In contrast, the median concentration of eBC does not show a seasonal trend. When evaluating the seasonal trends of the maximum concentrations, both the $\mathrm{PM}_{2.5}$ and $\mathrm{eBC}$ have much larger values in the dry seasons than during the rainy season; however, unlike the $\mathrm{PM}_{2.5}$ that also shows a significant increase between the CDS and WDS, the eBC actually decreases slightly between these two seasons, but not significantly (Table 2). There is a clear "weekend effect" that is seen in the maximum concentrations drawn in Fig. 6, and highlighted in Table 2. The concentrations decrease from workdays to Sundays over all seasons; however, unlike the $\mathrm{eBC}$ whose decreases are statistically significant over all seasons, the $\mathrm{PM}_{2.5}$ decreases are only significant during the RS and CDS.

The seasonal impacts on the optical properties of the aerosol particles are illustrated in Fig. 6c and d that show $B_{\text {scat }}$, and SSA, respectively. The figures suggest that the differences between seasons of $B_{\text {scat }}$ and SSA are small; however, as seen in Table 2, there are statistically quantifiable differences, although for $B_{\text {scat }}$, only the increase from RS to WDS is significant. The SSA values are much more sensitive to season, even though the median values do not appear that different. The SSA decreases from the RS to CDS but increases from the CDS to WDS. A decrease in the SSA can be a result of decreases in $B_{\text {scat }}$ or from increases in $B_{\text {abs }}$, since SSA is directly proportional to $B_{\text {scat }}$ and inversely proportional to $B_{\text {abs }}$; however, since $B_{\text {scat }}$ is seen to be relatively insensitive to seasonal changes, the changes with SSA are primarily a result of the seasonal sensitivity of $B_{\text {abs }}$, i.e., changes in the eBC. It should be noted that other aerosols like certain organics, as well as dust, will also absorb light, but at shorter wavelengths than the $870 \mathrm{~nm}$ used by the PAX. Hence, the majority of the absorption measured in this study is by $\mathrm{BC}$.

\subsection{Daily trends}

Figure 7a-c show the differences in the average daily UVA radiation (Fig. 7a), temperature (Fig. 7b) and relative humidity ( $\mathrm{RH}$, Fig. 7c). The UV radiation is averaged over the daylight hours from 10:00 to 16:00 local standard time (LST), whereas the temperature and RH are hourly averages. 

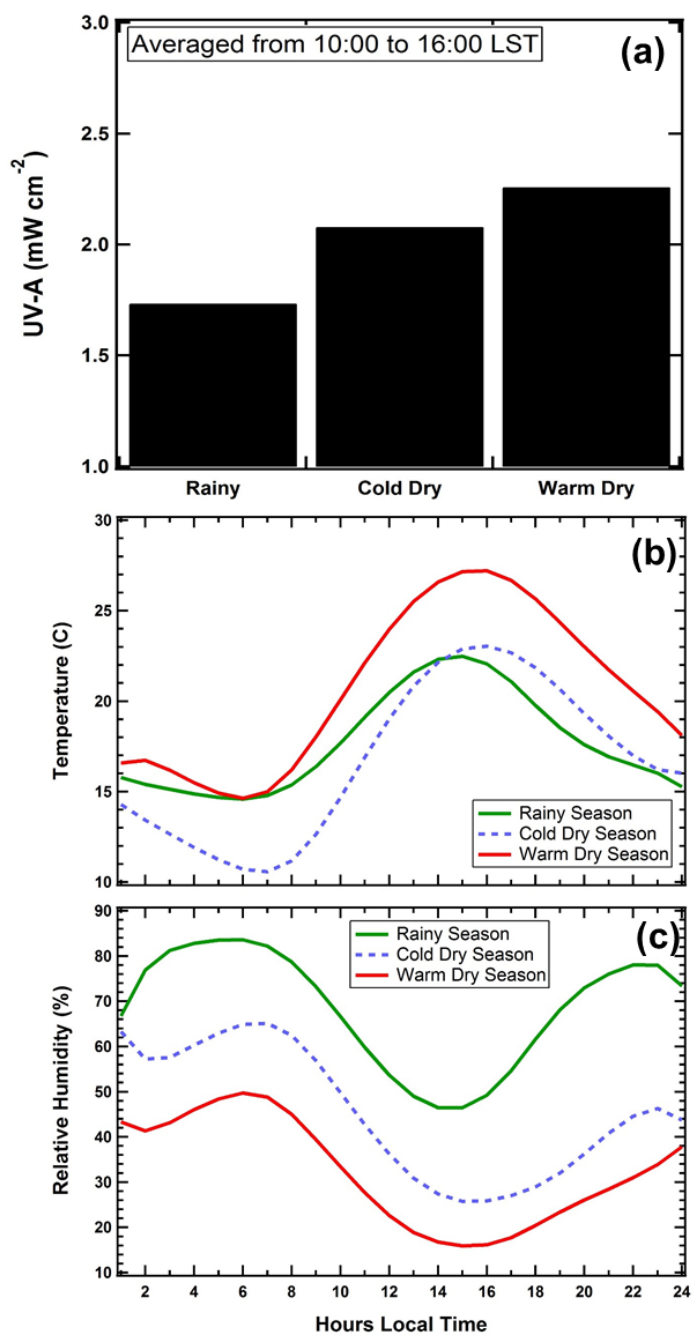

Figure 7. (a) The average daily accumulated UV-A is shown in the bar chart, illustrating the impact of clouds during the rainy season when the sun reaches its maximum elevation angle at the Mexico City latitude. The (b) average hourly and seasonal temperature and (c) relative humidity are separated by season: warm-dry (red), rainy (green) and cold-dry (blue).

In Fig. $7 b$ and c the red, green and blue curves differentiate the trends by season: WDS, RS and CDS, respectively. There is on average $30 \%$ more UV radiation in the CDS and WDS than during the RS. The WDS temperature (Fig. 7b) is generally about $5^{\circ}$ warmer than either the RS or CDS, except in the early mornings just before sunrise when the RS and WDS are the same. The WDS is always much drier throughout the day (Fig. 7c) than during the other seasons while the humidity during the rainy season is $30-50 \%$ higher than the dry seasons. As will be further discussed below, the seasonal radiation, temperature and humidity difference are principal factors that underlie the associated seasonal differences in gas and particle properties.
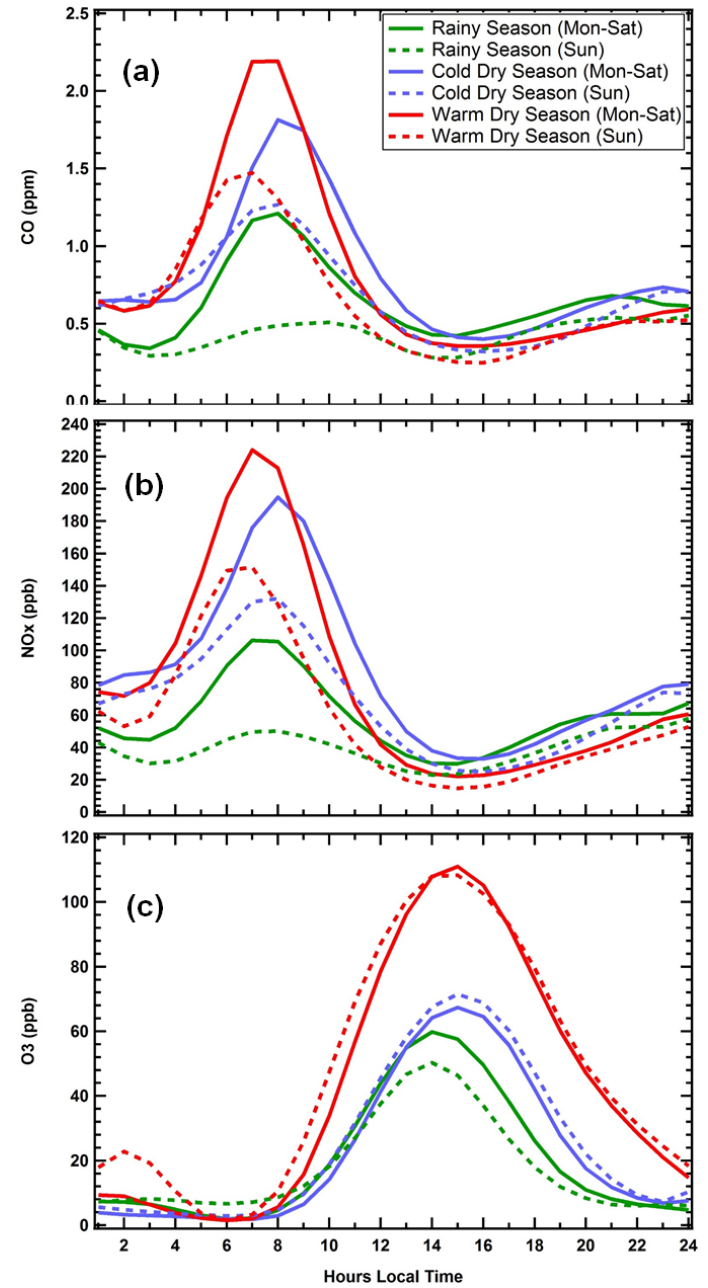

Figure 8. The average hourly values are shown, separated by workday (solid) and weekend (dashed) and by season: warm-dry (red), rainy (green) and cold-dry (blue) for (a) $\mathrm{CO}$, (b) $\mathrm{NO}_{x}$ and (c) $\mathrm{O}_{3}$ concentrations.

An examination of the average hourly properties of the pollutants, differentiated by season and by workday/Sunday, provides a different perspective than the comparison of just the daily quantiles and maxima that are shown in Figs. 5 and 6. All of the pollutants have daily cycles that are linked to the traffic patterns, photochemical processes and boundary layer depth (vertical mixing with clean air). Figure $7 \mathrm{a}-\mathrm{c}$ illustrate these cycles for $\mathrm{CO}, \mathrm{NO}_{x}$ and $\mathrm{O}_{3}$, respectively. The solid and dashed lines separate the measurements into the workdays (Monday-Saturday) and Sunday. The red, green and blue curves represent the seasons as described for Fig. $7 \mathrm{~b}$ and c.

The average hourly $\mathrm{CO}$ and $\mathrm{NO}_{x}$ (Fig. 8a, b) have very similar patterns over all three seasons. The maximum concentrations are reached between 07:00 and 08:00 LST during the RS and WDS and between 08:00 and 09:00 in the CDS, respectively. A secondary, broader maximum is seen near 
midnight, formed after the concentration begins increasing after the minimum at 16:00. As was illustrated in Fig. 5a, b, the maximum $\mathrm{CO}$ and $\mathrm{NO}_{x}$ values during the $\mathrm{RS}$ are ca. $40 \%$ lower than the dry seasons; however, when comparing the rRS with the WDS, this difference appears to be dominant only from about 04:00 to 11:00 LST. Outside of this time period the concentrations are nearly the same. Likewise, after 13:00 LST there is no longer a significant difference in the $\mathrm{CO}$ and $\mathrm{NO}_{x}$ concentrations in the RS and CDS. This is a result of the manner in which the vertical mixing progresses and the boundary layer depth increases during the three seasons. The shift in the time of the peaks between the CD and other seasons is due to the shift in Mexico from daylight savings time (DST) the first Sunday in November to standard time then back to DST the first Sunday in April; however, the measurement time base does not shift with changes in DST.

In the RS, as discussed previously, the boundary layer growth is accelerated by the vertical motions as convective clouds develop, resulting in much larger updrafts that reach higher in the troposphere than during the dry season. This leads to more rapid dilution of the primary emissions. At the same time, the clouds reduce the solar radiation, hence limiting photolysis and the photochemical reactions that produce $\mathrm{O}_{3}$ (Fig. 8c). In the dry seasons there is also vertical mixing but not as intense as during the rainy season, and it is only due to dry turbulent eddies within the boundary layer that slowly erode the inversion at the top by mixing with the free tropospheric air. There is less $\mathrm{O}_{3}$ during the CDS because the solar zenith angle is larger with subsequent decreased photochemical activity.

The minimum in concentrations at 16:00 LST, and steady increase thereafter, is due to the maximum boundary layer depth in late afternoon (Stull, 1988; Pérez-Vidal and Raga, 1998), followed by its gradual collapse as the solar insolation diminishes and the dilution decreases, while the daytime primary emissions remain more or less constant. There is actually an increase in emissions from traffic during the evening rush hour in Mexico City that contributes to the increase in $\mathrm{CO}$ and $\mathrm{NO}_{x}$ at night (Edgerton et al., 1999; Schifter et al., 2003)

A "weekend effect" (only Sunday) is also evident during all seasons whereby the maximum concentrations on Sundays are 50-70\% lower than on workdays (See Table 2) regardless of the time of day. Given that the meteorology on Sundays is not expected to differ from workdays, i.e., the boundary layer depth and solar radiation should not be dependent on the day of the week, this decrease over all seasons must be due to decreased, work-related traffic on Sundays.

The hourly average $\mathrm{O}_{3}$ (Fig. 8c) reaches the maximum concentrations between 13:00 and 14:00 LST during the rainy season and between 14:00 and 15:00 LST during the dry periods. Differences in the $\mathrm{O}_{3}$ concentrations between the rainy and cold-dry seasons are only obvious between the hours of approximately 14:00 and 20:00 LST and between
10:00 and midnight LST, when comparing the RS and WDS. The differences in $\mathrm{O}_{3}$ are primarily being driven by the photochemical production of $\mathrm{O}_{3}$. As summarized in Table 1, the CDS maximum $\mathrm{O}_{3}$ is $13 \%$ larger than the $\mathrm{RS}$, whereas the maximum during the warm-dry season is $47 \%$ larger. The impact of available solar radiation on the production of $\mathrm{O}_{3}$ from the precursor gases $\left(\mathrm{NO}_{x}\right.$ and VOCs) can be better understood by comparing measurements of the UV-A that are shown in Fig. 7a. The summer months of June-August are a period with minimum solar zenith angle; yet, as this figure shows, the daily averaged UV-A in the RS is about $20 \%$ less than the CDS and $30 \%$ less than the WDS. Hence, a major fraction of the difference between RS and WDS $\mathrm{O}_{3}$ can be explained by the decreased actinic flux in the RS with the remaining difference due to the increased vertical mixing produced by the cloud formation.

Figure $9 \mathrm{a}$ and $\mathrm{b}$ display the hourly trends in $\mathrm{PM}_{2.5}$ and $\mathrm{eBC}$ where it is seen that there are large differences, not only in the hourly concentrations that vary with season, but the hours during which these $\mathrm{PM}_{2.5}$ mass concentrations peak. These peak hours change with season, although the eBC to a lesser extent. The differences between the rainy and dry season $\mathrm{PM}_{2.5}$ maximum average mass concentrations are 36 and $56 \%$, respectively, when compared to the CDS and WDS (Table 2). For the eBC, these differences are 38 and $48 \%$. Whereas the $\mathrm{PM}_{2.5}$ concentrations during the CDS and WDS are always larger than those in the RS, regardless of the time of day, the eBC concentrations in the dry seasons only exceed those during the rainy season from approximately midnight until 12:00 LST. After this time the concentrations are the same on average. This is a reflection of the same atmospheric process that was discussed for $\mathrm{CO}$ and $\mathrm{NO}_{x}$, i.e., the difference in vertical mixing between the rainy and dry seasons. There is much greater dilution of the eBC during the rainy season, since clouds are responsible for the vertical mixing.

The daily cycles in $\mathrm{PM}_{2.5}$ have seasonal patterns that are much more distinctive than either the gases (Fig. $8 \mathrm{a}-\mathrm{c}$ ) or the $\mathrm{eBC}$. There is a slight shift in the hour of maximum concentrations for the eBC, between 06:00 and 07:00 for the RS and WDS, and between 07:00 and 08:00 for the CDS. This shift is only a result of the change from daylight savings time (DST) in November and April, so that in the CDS the major commuter traffic begins an hour later relative to the clock used on the RAMA data that doesn't change to DST. The $\mathrm{PM}_{2.5}$ reaches maximum concentrations between 07:00 and 08:00, 09:00 and 10:00 and 10:00 and 11:00, respectively, for the WDS, CS and RS. The large shift in the peaks of the daily cycles is the result of both the atmospheric dynamics, i.e., boundary layer growth, and the chemical processes behind the formation and growth of the particles that make up the $\mathrm{PM}_{2.5}$.

There is a very distinctive "weekend effect" displayed in the eBC and $\mathrm{PM}_{2.5}$ concentrations. As summarized in Table 2, the maximum eBC concentrations decrease by more than $50 \%$ from workdays to Sundays during all seasons. As 

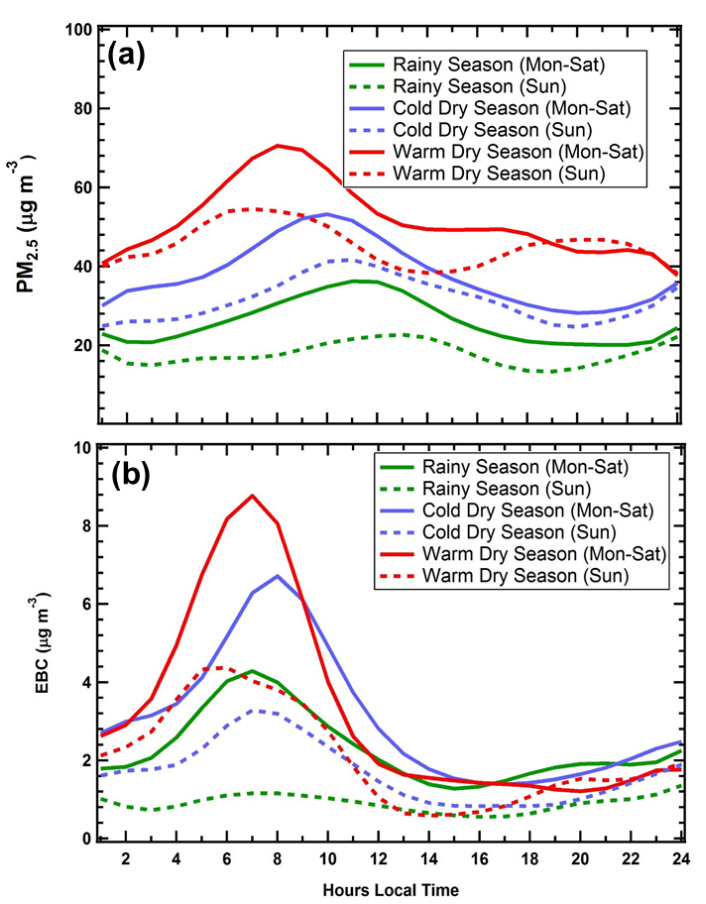

Figure 9. As in Fig. 8, the average hourly (a) $\mathrm{PM}_{2.5}$ mass and (b) equivalent black carbon concentrations are shown, differentiated by seasons and day of the week.

can be observed in Fig. 9b, the difference is distinct over all hours of the day but is the most predominant between around 05:00 to 18:00. One of the major differences in primary emissions of $\mathrm{BC}$ between workdays and Sundays is that the use of large, diesel-burning trucks and machinery is much less on Sundays. Although vehicular traffic in general is much less on Sundays, since combustion of diesel fuel is the major contributor of $\mathrm{BC}$ emissions in the city, the large decrease in $\mathrm{BC}$ is linked more to the decrease in diesel combustion than gasoline. To support this assertion, looking only at the dry season to remove any effects of precipitation, the average $\mathrm{eBC}$ to $\mathrm{CO}$ ratio on workdays was $3.6 \mu \mathrm{g} \mathrm{m}^{-3}$ of $\mathrm{eBC}$ to $1.0 \mathrm{ppm}$ of $\mathrm{CO}$. This compared to the Sunday ratio that is $2.1 \mu \mathrm{g} \mathrm{m}^{-3}$ of eBC to $1.0 \mathrm{ppm}$ of $\mathrm{CO}$; hence, the $\mathrm{eBC}$ decreases by a much larger percentage than the $\mathrm{CO}$.

The hourly trends in the optical properties of the aerosol particles, $B_{\text {scat }}$ and SSA, are shown in Fig. 10a and $\mathrm{b}$, respectively. The maximum $B_{\text {scat }}$ falls between 09:00 and 10:00 LST during the WDS and between 10:00 and 11:00 LST in the RS and CDS. Unlike the particle mass concentrations of $\mathrm{PM}_{2.5}$ and $\mathrm{eBC}$, there are no distinct differences from season to season in the maximum values. The differences are instead seen in the morning hours before reaching the maximum then again in the afternoon. During both of these periods the dry season values are about $30 \%$ larger than the rainy period. In the same way that the trends in $\mathrm{PM}_{2.5}$ are a balance between the processes that drive particle growth and the dynamic processes that dilute the number concentration, likewise the trends in the scattering are driven by complex interactions. The intensity of light scattering and the $\mathrm{PM}_{2.5}$ mass concentrations are strongly correlated because both are proportional to particle concentration and size. The $B_{\text {scat }}$ and $\mathrm{PM}_{2.5}$ values peak at the same time periods during the three seasons (Figs. 9a and 10a).

The SSA reaches its minimum value in the morning between 06:00 and 07:00 LST in the WDS and RS and between 07:00 and 08:00 LST in the CDS. As mentioned previously, the SSA appears to be much more sensitive to changes in eBC, i.e., light absorption, than in $B_{\text {scat }}$. Since the minimum in the SSA corresponds to the maximum in the $\mathrm{eBC}$ this further reinforces the sensitivity of SSA to changes in the eBC concentration in this environment. The changes with season of the SSA do not mirror those of eBC. Whereas the maximum eBC in the dry seasons was significantly larger than the rainy season (Table 2), the trends in the SSA are more complicated with the RS and WDS values being nearly equal until they separate after midday at 13:00 LST, with the RS SSA decreasing while the WDS maintains an almost constant value. These trends can be best understood by comparing the trends in $\mathrm{PM}_{2.5}$, the parameter that is correlated with Bscat, and $\mathrm{eBC}$ and observing that while the eBC decreases rapidly after its morning maximum during all seasons, the $\mathrm{PM}_{2.5}$ is decreasing much more slowly, due to photochemical reactions leading to the growth of pre-existing particles (Baumgardner et al., 2004) and to the secondary production of particles (e.g., de Gouw et al., 2009; Herndon et al., 2008). This illustrates that whereas the minimum in SSA observed during the morning is being driven by the presence of particles with $\mathrm{eBC}$, the afternoon SSA is being driven mainly by changes in non-absorbing particles represented by $B_{\text {scat }}$.

\subsection{Correlations and causal links between co-pollutants}

In addition to deducing the potential relationships between co-pollutants by comparing the hourly trends in Figs. 8, 9 and 10 , these links can be further investigated by calculating the cross correlations to highlight the temporal shifts that may change with season and might offer additional evidence of how photochemical and thermodynamic processes drive the daily trends in gas concentrations and particle properties.

Figures 11-13 are correlations between pairs of pollutants, as a function of the lag time that is varied from -10 to $+10 \mathrm{~h}$, in 10 min increments. The vertical black dashed line is drawn at the zero lag time and the horizontal black dashed line is drawn at the crossover point from positive to negative correlation. The colors of the lines denote the season using the same coding as previous figures. Figure 11a illustrates the relationship between $\mathrm{CO}$ and $\mathrm{NO}_{x}$ and indicates that these two pollutants are highly correlated $(R=0.9)$ with no lag time, i.e., they are being produced at the same time and likely by the same sources. The correlation between $\mathrm{O}_{3}$ and $\mathrm{NO}_{x}$ (Fig. 11b), shows that their highest correlations are at lag 

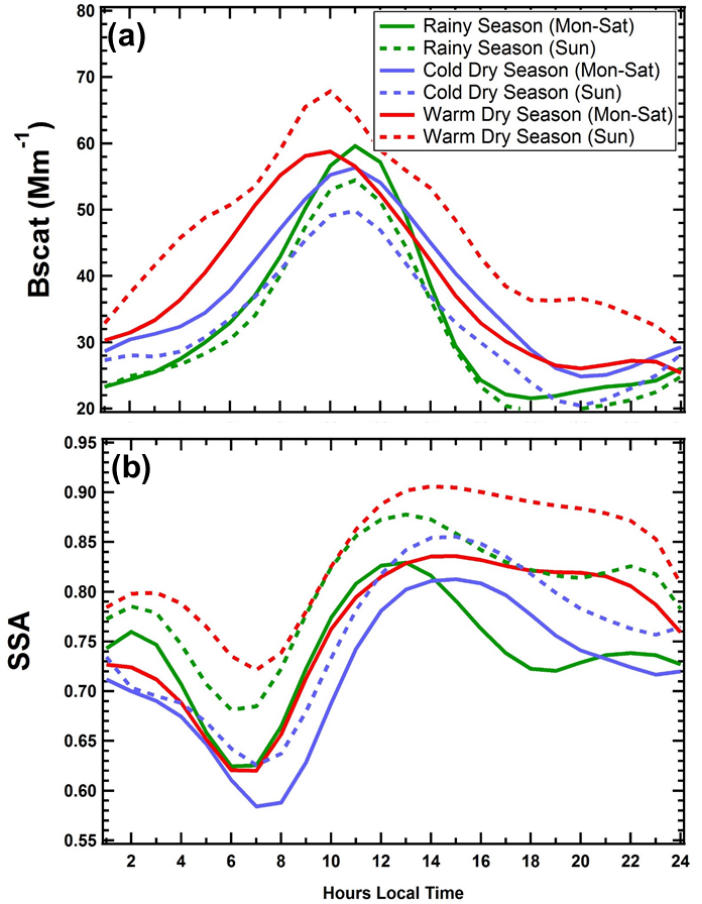

Figure 10. As in Figs. 8 and 9 but for (a) the light-scattering coefficient, Bscat, and (b) the single scattering albedo, SSA.

times of $-8,-7.5$ and $-7 \mathrm{~h}$, for the WDS, CDS and RS, respectively. The maximum correlation at negative lag indicates that $\mathrm{O}_{3}$ is linked to the $\mathrm{NO}_{x}$ that was formed approximately $8 \mathrm{~h}$ earlier, an expected correlation. These lag times are just another way of quantifying the time differences between the peaks in $\mathrm{NO}_{x}$ and $\mathrm{O}_{3}$ that were seen in Fig. $8 \mathrm{~b}$ and $\mathrm{c}$. The $1 \mathrm{~h}$ difference between the CDS and WDS is caused by the change in DST as was explained earlier for the daily trends.

There is additional information contained in these cross correlations by evaluating the time from maximum to zero correlation. The time at which the correlation coefficient crosses the zero point is a measure of a characteristic timescale, referred to as the integral timescale, that is related to the rate at which atmospheric processes produce, dilute or remove the pollutants. This integral timescale indicates how quickly two pollutants are being de-correlated by dilution and mixing with other atmospheric components. For example, there is a single, season-independent integral timescale for the $\mathrm{CO}$ and $\mathrm{NO}_{x}$ correlation, 4-5h, whereas for the $\mathrm{O}_{3}$ and $\mathrm{NO}_{x}$ there are three timescales: 5, 4.5 and $4 \mathrm{~h}$, respectively, for the CDS, WDS and RS.

The $\mathrm{eBC}$ and $\mathrm{CO}$ concentrations are highly correlated $(R>0.8)$ with no lag as seen in Fig. 12a, indicating that their sources are located in the same region. The high correlation between $\mathrm{CO}$ and $\mathrm{BC}$ mass (derived by an alternative method) in Mexico City was already reported by Baumgard-

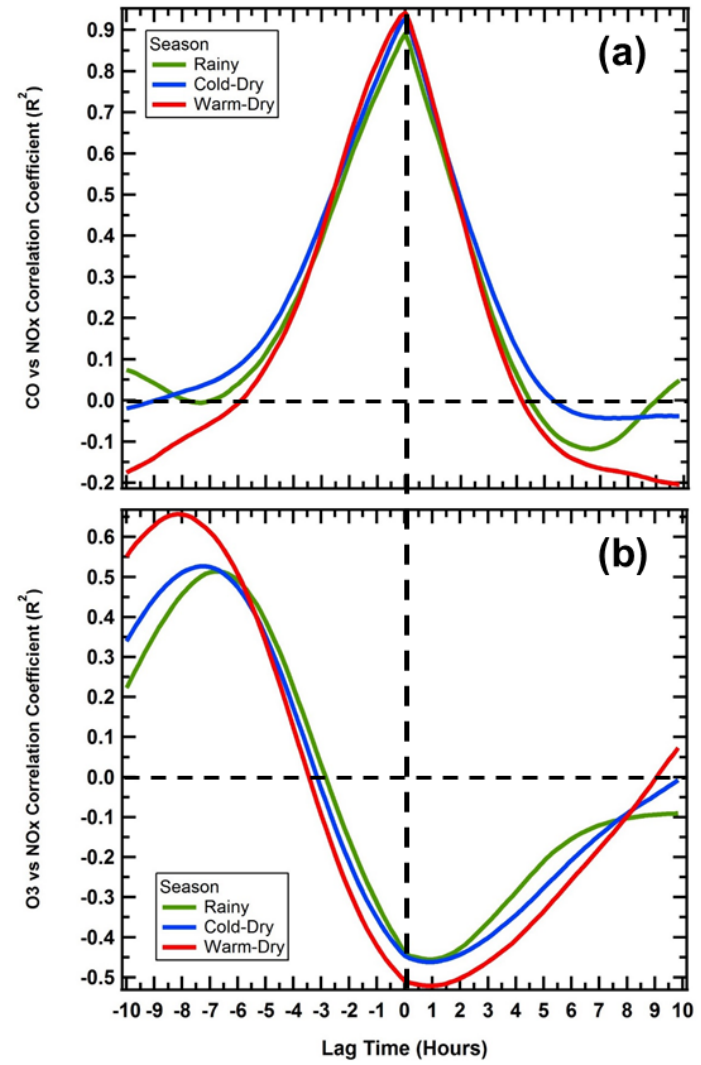

Figure 11. These plots illustrate the correlations between (a) $\mathrm{CO}$ and $\mathrm{NO}_{x}$, (b), $\mathrm{O}_{3}$ and $\mathrm{NO}_{x}$, as a function of the lag time and differentiated by season. The vertical dashed line shows the correlation of the parameters at no lag time. The horizontal dashed line demarks the crossover from positive to negative correlation. The lag time was varied by $10 \mathrm{~min}$ intervals.

ner et al. (2000, 2002). The integral timescales are 6, 7 and $8.5 \mathrm{~h}$ during the WDS, RS and CDS, respectively.

The cross-correlation between the eBC and $\mathrm{PM}_{2.5}$ (Fig. 12b) presents a more complicated picture that is related to the complex relationship between the black carbon that is produced by primary emissions and particle mass that is a mixture of primary and secondary processes. Looking at the average maximum values in Table 2 , we see that $\mathrm{eBC}$ is approximately $20 \%$ of the mass of $\mathrm{PM}_{2.5}$. Hence, the good correlation at zero lag for all seasons represents the fraction of the $\mathrm{PM}_{2.5}$ that is made up of $\mathrm{BC}$. The trends in the correlation coefficients rapidly diverge as the lag time increases. This reflects the secondary processes that either produce new particles or lead to the increase in mass of existing particles. These secondary processes can be aqueous, photochemical or a combination of both, so the rate at which particles grow will depend on the temperature, relative humidity, $\mathrm{pH}$ and UV radiation flux. Since BC is a primary particle onto which organics, sulfates or nitrates can condense, a correlation between $\mathrm{BC}$ and $\mathrm{PM}_{2.5}$ will remain. As the $\mathrm{BC}$ particle evolves 

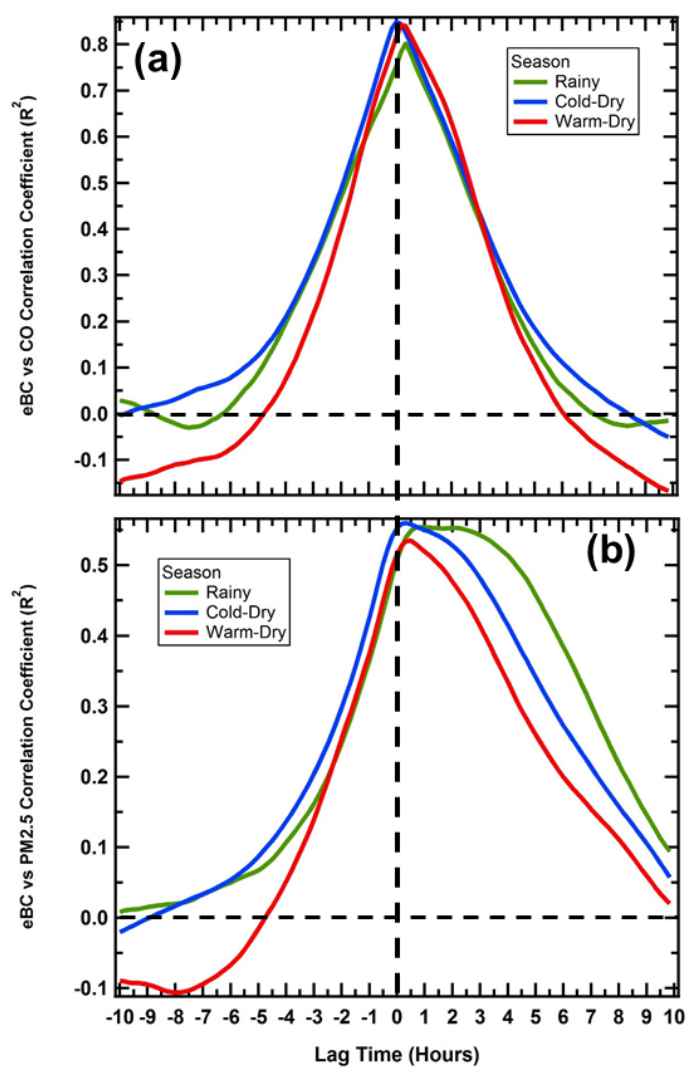

Figure 12. As in Fig. 11, these plots illustrate the correlations between (a) $\mathrm{eBC}$ and $\mathrm{CO}$, and (b) $\mathrm{eBC}$ and $\mathrm{PM}_{2.5}$, as a function of the lag time and differentiated by season.

and takes on a coating or mixture of other substances, when it is measured by the PAX it will continue to absorb energy and be identified as eBC, i.e., there is still a "memory" of the original particles that are being emitted even over very long lag times. As Fig. 12b illustrates, the integral timescales exceed $10 \mathrm{~h}$ during all seasons. The much larger integral timescale of the rainy season is most likely due to the higher humidity during this period that promotes aqueous-phase reactions and particle growth. During the dry seasons, the secondary processes are only related to photochemical reactions. These interpretations are purely speculative without corroboration using a chemical growth model, which is beyond the scope of this current study.

The correlations between the particle optical properties ( $B_{\text {scat }}$ and SSA) and the $\mathrm{eBC}$ and $\mathrm{PM}_{2.5}$ are displayed in Fig. 13a, b. The relationship between $B_{\text {scat }}$ and $\mathrm{PM}_{2.5}$ that was discussed previously is highlighted in Fig. 13a, showing a correlation coefficient $>0.8$ at zero lag time. The very long integral timescale is a result of the same complex processes that led to the greater than $10 \mathrm{~h}$ timescales for the eBC and $\mathrm{PM}_{2.5}$ (Fig. 12b). Figure 13b underscores the earlier discussion about the sensitivity of the SSA to eBC. The negative correlation is due to the inverse relationship between SSA

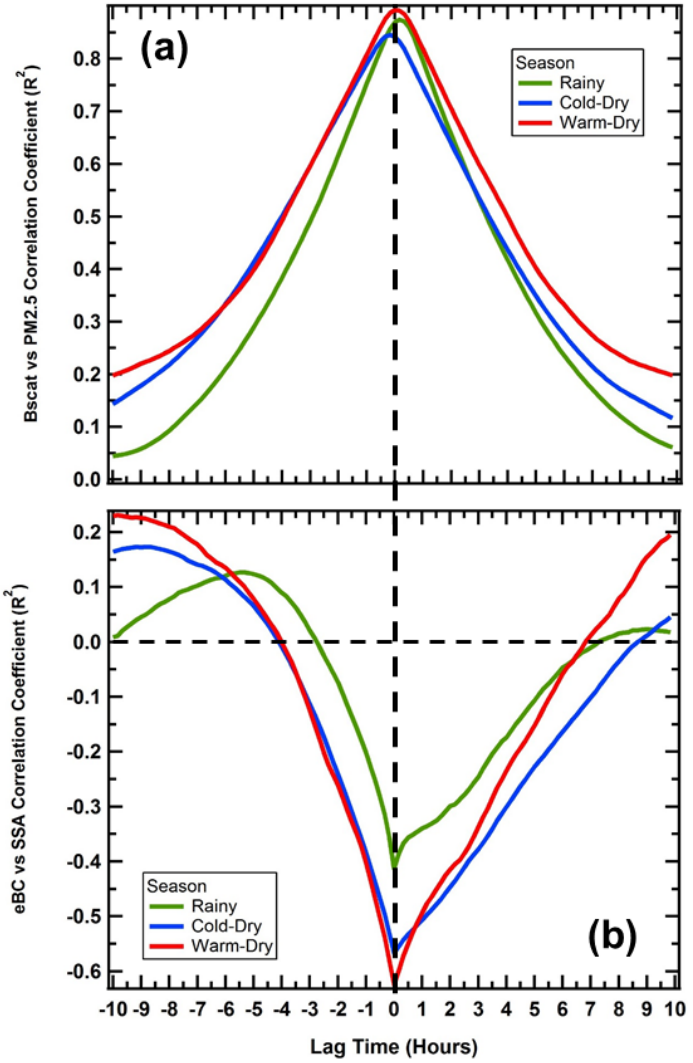

Figure 13. As in Fig. 12, these plots illustrate the correlations between (a) Bscat and $\mathrm{PM}_{2.5}$ and (b) eBC and SSA, as a function of the lag time and differentiated by season.

and $\mathrm{eBC}$. The correlations are higher in the dry months than in the rainy season because of the additional contribution to light scattering by the particles that are formed under conditions of high humidity in the RS. The separation in the integral timescales is also linked to the relative rate by which the $B_{\text {scat }}$ increases as secondary processes promote particle growth in the different seasons.

\section{Summary and conclusions}

Measurements of SLCPs and precursor gases, made over a 13 month period from 6 March 2013 to 31 March 2014, have been evaluated to document and explain the seasonal trends related to changes in meteorology and radiative fluxes. The SLCPs that were analyzed are the $\mathrm{eBC}, \mathrm{O}_{3}$ and $\mathrm{PM}_{2.5}$ along with the co-pollutant gases of $\mathrm{CO}$ and $\mathrm{NO}_{x}$. The eBC data are the longest, continuous measurements that have ever been conducted in Mexico City. These data extend over the three primary seasons in Mexico City, i.e., rainy, cold and dry and warm and dry, and provide the basis for linking daily trends to the underlying physicochemical processes that drive them.

The maximum concentrations of the gases and particles were significantly less in the rainy season compared to the 
dry seasons. The maximum concentration changes from the rainy to dry seasons were: $\mathrm{eBC} 8.8$ to $13.1 \mu \mathrm{g} \mathrm{m}^{-3}$ (44\%), $\mathrm{PM}_{2.5}$ from 49 to $73 \mu \mathrm{g} \mathrm{m}^{-3}$ (61\%), $\mathrm{NO}_{x}$ from 144 to $252 \mathrm{ppm}(78 \%), \mathrm{O}_{3}$ from 73 to $100 \mathrm{ppb}(51 \%)$ and $\mathrm{CO}$ from 2.5 to $3.8 \mathrm{ppm}(75 \%)$. The primary factor that leads to lower concentrations in the rainy season is morning cloud formation that produces vigorous vertical motions and results in the dilution of all the pollutants. The clouds also reduce solar energy (UV radiation) and decrease the photochemical reactions that produce ozone and secondary aerosol particles. The other factor that will primarily impact the particle population is the precipitation during the rainy season that can remove the aerosol particle by inertial scavenging. The magnitude of this effect requires an analysis beyond the scope of the current study but given the almost daily rain rates of more than $2 \mathrm{~mm}$, this source of particle removal could be of a similar magnitude as vertical mixing as the cause for decreased particle concentrations in the rainy season.

A "weekend effect" is observed that is linked to changes in traffic patterns and the type of fuel burned. Significant decreases ( $t$ test) are observed between workdays (Monday through Saturday) and Sundays in the concentrations of CO, $\mathrm{NO}_{x}, \mathrm{eBC}$ and $\mathrm{PM}_{2.5}$. This decrease is most likely a result of reduced emissions by diesel-burning vehicles. A significant increase is seen in the SSA because of its sensitivity and inverse relationship to changes in the light-absorbing eBC. A significant effect was also seen in $\mathrm{O}_{3}$ concentrations that did not change from workdays to Sundays because of decreased production from VOCs that was balanced by decreased inhibition by $\mathrm{NO}_{x}$.

Cross correlations and the derived integral timescales were calculated between the co-pollutants in order to establish the temporal links and de-correlation times. Shorter integral timescales are related to rapid vertical mixing that erodes the "memory" of the pollutants that are originally coupled to the same source or location where they are produced. Cross correlations between pollutants where one or both can be affected by secondary chemical reactions typically have much longer integral timescales since these secondary reactions extend the memory of the coupled co-pollutants.

The maximum concentrations of eBC measured in 2000 (Baumgardner et al., 2002) and 2006 (Marley et al., 2009a, b), were 9.1 and $9.4 \mu \mathrm{g} \mathrm{m}^{-3}$, respectively, compared to 8.8 and $13.1 \mathrm{\mu g} \mathrm{m}^{-3}$ in the wet and dry seasons between March 2013 and March 2014. Not only are these exceptionally large concentrations of a type of particle that has been specifically identified by the World Health Organization as being hazardous to health, there has been no significant change in the $\mathrm{eBC}$ emissions, within the estimated uncertainties of more than $60 \%$, over a 15 year period. The efforts of the city government to reduce some of the pollutants have been highly successful in reducing $\mathrm{CO}$ and $\mathrm{O}_{3}$; however, the mitigation strategies target gases more than particles. Given that the fleet of vehicles that emit BC has grown from 210000 trucks and buses in 2000 to almost 350000 in
2014 , it is encouraging that the $\mathrm{BC}$ has remained more or less constant for this same time period. This would suggest that some of the strategies to reduce emissions are partially mitigating the effects of $\mathrm{BC}$ despite the increase in vehicles. As the time of writing, Mexico is planning to adopt the European standard for diesel fuel that will decrease the emissions of $\mathrm{BC}$ and possibly counter the impact of a higher density of vehicles.

Acknowledgements. We acknowledge Olivia Rivera-Hernández, Miguel Sánchez-Rodríguez and Alfonso López-Medina for providing criteria pollutants data and Angelica Neria-Hernández for her support of the PAX operation.

Edited by: E. Gerasopoulos

\section{References}

Arnott, W. P, Moosmüller, H., and Walker, J. W.: Nitrogen Dioxide and Kerosene-Fla.me Soot Calibration of Photoacoustic Instruments for Measurement of Light Absorption by Aerosols, Rev. Sci. Instrum., 71, 4545-4552, 2000.

Arnott, W. P., Hamasha K., Moosmüller, H., Sheridan P. J., and Ogren J. A.: Towards Aerosol Light-Absorption Measurements with a 7-Wavelength Aethalometer: Evaluation with a Photoacoustic Instrument and 3-Wavelength Nephelometer, Aerosol Sci. Tech., 39, 17-29, 2005.

Arnott, W. P., Walker, J. W., Moosmüller, H., Elleman, R. A., Jonsson, H. H., Buzorius, G., Conant, W. C., Flagan, R. C., and Seinfeld, J. H.: Photoacoustic insight for aerosol light absorption aloft from meteorological aircraft and comparison with particle soot absorption photometer measurements: DOE Southern Great Plains climate research facility and coastal stratocumulus imposed perturbation experiments, J. Geophys. Res.-Atmos., 111, D05S02, doi:10.1029/2005JD005964, 2006.

Baron, P. A. and Willeke, K.: Aerosol Measurements Principles, Techniques and Applications, John Wiley and Sons, New York, NY, 1133 pp., 2001.

Barth, M. C. and Church, A. T.: Regional and global distributions and lifetimes of sulfate aerosols from Mexico City and southeast China, J. Geophy. Res, 104, 30231-30239. 1999.

Baumgardner, D., Raga, G. B., Kok, G., Ogren, J., Rosas, I., Baez, A., and Novakov, T.: On the Evolution of Aerosol Properties at a Mountain Site Above Mexico City, J. Geophys. Res., 105, 22243-22253, 2000.

Baumgardner, D., Raga, G., Peralta, O., Rosas, I., Castro, T., Kuhlbusch, T., John, A., and Petzold, A.: Diagnosing black carbon trends in large urban areas using carbon monoxide measurements, J. Geophys. Res., 107, 8342, doi:10.1029/2001JD000626, 2002.

Baumgardner, D., Raga, G. B., and Muhlia, A.: Evidence for the formation of $\mathrm{CCN}$ by photochemical processes in Mexico City, Atmos. Environ., 38, 357-367, 2004.

Baumgardner, D., Kok, G. L., and Raga, G. B.: On the diurnal variability of particle properties related to light absorbing carbon in Mexico City, Atmos. Chem. Phys., 7, 2517-2526, doi:10.5194/acp-7-2517-2007, 2007. 
Baumgardner, D., Grutter, M., Allan, J., Ochoa, C., Rappenglueck, B., Russell, L. M., and Arnott, P.: Physical and chemical properties of the regional mixed layer of Mexico's Megapolis, Atmos. Chem. Phys., 9, 5711-5727, doi:10.5194/acp-9-5711-2009, 2009.

Bond, T. C., Habib, G., and Bergstrom, R. W.: Limitations in the enhancement of visible light absorption due to mixing state, J. Geophys. Res., 111, 211, doi:10.1029/2006JD007315, 2006.

Bond, T. C., Doherty, S. J., Fahey, D. W., Forster, P. M., Berntsen, T., DeAngelo, B. J., Flanner, M. G., Ghan, S., Kärcher, B., Koch, D., Kinne, S., Kondo, Y., Quinn, P. K., Sarofim, M. C., Schultz, M. G., Schulz, M., Venkataraman, C., Zhang, H., Zhang, S., Bellouin, N., Guttikunda, S. K., Hopke, P. K., Jacobson, M. Z., Kaiser, J. W., Klimont, Z., Lohmann, U., Schwarz, J. P., Shindell, D., Storelvmo, T., Warren, S. G., and Zender, C. S.: Bounding the role of black carbon in the climate system: A scientific assessment, J. Geophys. Res.-Atmos., 188, 5380-5552, 2013.

Bowerman, N. H. A., Frame, D. J. Huntingford, C., Lowe, J. A., Smith, S. M., and Allen, M. R.: The role of short-lived climate pollutants in meeting temperature goals, Nature Climate Change, 3, 1021-1024, 2013.

Chan, T. W., Brook, J. R., Smallwood, G. J., and Lu, G.: Time-resolved measurements of black carbon light absorption enhancement in urban and near-urban locations of southern Ontario, Canada, Atmos. Chem. Phys., 11, 10407-10432, doi:10.5194/acp-11-10407-2011, 2011.

Collins, C. O. and Scott, S. L.: Air pollution in the valley of Mexico, Geogr. Rev., 2, 119-133, 1993.

de Gouw, J. A., Welsh-Bon, D., Warneke, C., Kuster, W. C., Alexander, L., Baker, A. K., Beyersdorf, A. J., Blake, D. R., Canagaratna, M., Celada, A. T., Huey, L. G., Junkermann, W., Onasch, T. B., Salcido, A., Sjostedt, S. J., Sullivan, A. P., Tanner, D. J., Vargas, O., Weber, R. J., Worsnop, D. R., Yu, X. Y., and Zaveri, R.: Emission and chemistry of organic carbon in the gas and aerosol phase at a sub-urban site near Mexico City in March 2006 during the MILAGRO study, Atmos. Chem. Phys., 9, 34253442, doi:10.5194/acp-9-3425-2009, 2009.

Edgerton, S. A., Arriaga, J. L., Archuleta, J., Bian, X., Bossert, J. E., Chow, J. C., Coulter, R. L., Doran, J. C., Doskey, P. V., Elliot, S., Fast, J. D., Gaffney, J. S., Guzman, F., Hubbe, J. M., Lee, J. T., Malone, E. L., Marley, N. A., McNair, L. A., Neff, W., Ortiz, E., Petty, R., Ruiz, M., Shaw, W. J., Sosa, G., Vega, E., Watson, J. G., Whiteman, C. D., and Zhong, S: Particulate air pollution in Mexico City: A collaborative research project, J. Air Waste Manage. Assoc., 49, 1221-1229, 1999.

Herndon, S. C., Onasch, T. B., Wood, E. C., Kroll, J. H., Canagaratna, M. R., Jayne, J. T., Zavala, M. A., Knighton, W. B., Mazzoleni, C., Dubey, M. K., Ulbrich, I. M., Jimenez, J. L., Seila, R., de Gouw, J. A., de Foy, B., Fast, J., Molina, L. T., Kolb, C. E., and Worsnop, D. R.: The correlation of secondary organic aerosol with odd oxygen in a megacity outflow, Geophys. Res. Lett., 35, L15804, doi:10.1029/2008GL034058, 2008.

Holder, A. L., Hagler, G. S. W., Yelverton, T. L. B., and Hays, M. D.: On-road black carbon instrument intercomparison and aerosol characteristics by driving environment, Atmos. Environ., 88, 183-191, 2014.

Jáuregui, E.: Mesomicroclima de la Ciudad de México, Instituto de Geografía, UNAM, 87 pp., 1971.
Jiang, M., Marr, L. C., Dunlea, E. J., Herndon, S. C., Jayne, J. T., Kolb, C. E., Knighton, W. B., Rogers, T. M., Zavala, M., Molina, L. T., and Molina, M. J.: Vehicle fleet emissions of black carbon, polycyclic aromatic hydrocarbons, and other pollutants measured by a mobile laboratory in Mexico City, Atmos. Chem. Phys., 5, 3377-3387, doi:10.5194/acp-5-3377-2005, 2005.

Johnson, K. S., Zuberi, B., Molina, L. T., Molina, M. J., Iedema, M. J., Cowin, J. P., Gaspar, D. J., Wang, C., and Laskin, A.: Processing of soot in an urban environment: case study from the Mexico City Metropolitan Area, Atmos. Chem. Phys., 5, 3033-3043, doi:10.5194/acp-5-3033-2005, 2005.

Lewis, K. A., Arnott, W. P., Moosmüller, H., Chakrabarty, R. K., Carrico, C. M., Kreidenweis, S. M., Day, D. E., Malm, W. C., Laskin, A., Jimenez, J. L., Ulbrich, I. M., Huffman, J. A., Onasch, T. B., Trimborn, A., Liu, L., and Mishchenko, M. I.: Reduction in biomass burning aerosol light absorption upon humidification: roles of inorganically-induced hygroscopicity, particle collapse, and photoacoustic heat and mass transfer, Atmos. Chem. Phys., 9, 8949-8966, doi:10.5194/acp-9-8949-2009, 2009.

Liu, S., Aiken, A. C., Arata, C., Dubey, M. K., Stockwell, C. E., Yokelson, R. J., Stone, E. A., Jayarathne, T., Robinson, A. L., DeMott, P. J., and Kreidenweis, S. M.: Aerosol single scattering albedo dependence on biomass combustion efficiency: Laboratory and field studies, Geophys. Res. Lett., 41, 742-748, 2014.

Marley, N. A., Gaffney, J. S., Ramos-Villegas, R., and Cárdenas González, B.: Comparison of measurements of peroxyacyl nitrates and primary carbonaceous aerosol concentrations in Mexico City determined in 1997 and 2003, Atmos. Chem. Phys., 7, 2277-2285, doi:10.5194/acp-7-2277-2007, 2007.

Marley, N. A., Gaffney, J. S., Tackett, M., Sturchio, N. C., Heraty, L., Martinez, N., Hardy, K. D., Marchany-Rivera, A., Guilderson, T., MacMillan, A., and Steelman, K.: The impact of biogenic carbon sources on aerosol absorption in Mexico City, Atmos. Chem. Phys., 9, 1537-1549, doi:10.5194/acp-9-1537-2009, 2009a.

Marley, N. A., Gaffney, J. S., Castro, T., Salcido, A., and Frederick, J.: Measurements of aerosol absorption and scattering in the Mexico City Metropolitan Area during the MILAGRO field campaign: a comparison of results from the T0 and T1 sites, Atmos. Chem. Phys., 9, 189-206, doi:10.5194/acp-9-189-2009, 2009b.

Molina, L. T., Kolb, C. E., de Foy, B., Lamb, B. K., Brune, W. H., Jimenez, J. L., Ramos-Villegas, R., Sarmiento, J., ParamoFigueroa, V. H., Cardenas, B., Gutierrez-Avedoy, V., and Molina, M. J.: Air quality in North America's most populous city overview of the MCMA-2003 campaign, Atmos. Chem. Phys., 7, 2447-2473, doi:10.5194/acp-7-2447-2007, 2007.

Molina, L. T., Madronich, S., Gaffney, J. S., Apel, E., de Foy, B., Fast, J., Ferrare, R., Herndon, S., Jimenez, J. L., Lamb, B., Osornio-Vargas, A. R., Russell, P., Schauer, J. J., Stevens, P. S., Volkamer, R., and Zavala, M.: An overview of the MILAGRO 2006 Campaign: Mexico City emissions and their transport and transformation, Atmos. Chem. Phys., 10, 8697-8760, doi:10.5194/acp-10-8697-2010, 2010.

Moosmüller, H., Chakrabarty R. K., and Arnott, W. P.: Aerosol Light Absorption and its Measurement: A Review, J. Quant. Spectrosc. Ra., 110, 844-878, 2009.

Murphy, D.: The effect of water evaporation on photoacoustic signals in transition and molecular flow, Aerosol Sci. Tech., 43, 356-364, 2009. 
Nakayama, T., Suzuki, H., Kagamitani, S., Ikeda, Y., Uchiyama, A., and Matsumi, Y.: "Characterization of a three wavelength photoacoustic soot spectrometer (PASS-3) and photoacoustic extinctiometer (PAX)", J. Meteorol. Soc. Jpn., 93, 285-308, doi:10.2151/jmsj.2015-016, 2015.

Pérez Vidal, H. and Raga, G. B.: On the vertical distribution of pollutants in Mexico City, Atmósfera, 11, 95-108, 1998.

Petzold, A., Ogren, J. A., Fiebig, M., Laj, P., Li, S.-M., Baltensperger, U., Holzer-Popp, T., Kinne, S., Pappalardo, G., Sugimoto, N., Wehrli, C., Wiedensohler, A., and Zhang, X.-Y.: Recommendations for reporting "black carbon" measurements, Atmos. Chem. Phys., 13, 8365-8379, doi:10.5194/acp-13-83652013, 2013.

Schifter ,I., Díaz, L., Durán, J., Guzmán, E., Chávez, O., and LópezSalinas, E.: Remote Sensing Study of Emissions from Motor Vehicles in the Metropolitan Area of Mexico City, Environ. Sci. Technol., 37, 395-401, 2003.

Shindell, D., Kuylenstierna, J. C. I., Vignati, E., van Dingenen, R., Amann, M., Klimont, Z., Anenberg, S. C., Muller, N., JanssensMaenhout, G., Raes, F., Schwartz, J., Faluvegi, G., Pozzoli, L., Kupiainen, K., Höglund-Isaksson, L., Emberson, L., Streets, D., Ramanathan, V., Hicks, K., Kim Oanh, N. T., Milly, G., Williams, M., Demkine, V., and Fowler, D.: Simultaneously mitigating near-term climate change and improving human health and food security, Science, 335, 183-189, 2012.
Singh, H. B., Brune, W. H., Crawford, J. H., Flocke, F., and Jacob, D. J.: Chemistry and transport of pollution over the Gulf of Mexico and the Pacific: spring 2006 INTEX-B campaign overview and first results, Atmos. Chem. Phys., 9, 2301-2318, doi:10.5194/acp-9-2301-2009, 2009

SMA-GDF (Secretaria del Medio Ambiente del Gobierno del Distrito Federal): Inventario de emisiones contaminantes y de efecto invernadero el año de 2012 de la Zona Metropolitana del Valle de México, Secretaría del Medio Ambiente, Gobierno de México, México, available at: http://www.aire.df.gob.mx/, last access: 27 August 2015.

Stephens, S., Madronich, S., Wu, F., Olson, J. B., Ramos, R., Retama, A., and Muñoz, R.: Weekly patterns of México City's surface concentrations of $\mathrm{CO}, \mathrm{NO}_{x}, \mathrm{PM}_{10}$ and $\mathrm{O}_{3}$ during 19862007, Atmos. Chem. Phys., 8, 5313-5325, doi:10.5194/acp-85313-2008, 2008.

Stull, R.: An Introduction to Boundary Layer Meteorology, Atmospheric and Oceanographic Library, Volume 13, Springer, New York, New York, 670 pp., 1988.

Subramanian, R., Kok, G. L., Baumgardner, D., Clarke, A., Shinozuka, Y., Campos, T. L., Heizer, C. G., Stephens, B. B., de Foy, B., Voss, P. B., and Zaveri, R. A.: Black carbon over Mexico: the effect of atmospheric transport on mixing state, mass absorption cross-section, and BC/CO ratios, Atmos. Chem. Phys., 10, 219 237, doi:10.5194/acp-10-219-2010, 2010. 